\title{
Calcitriol Accelerates Vascular Calcification Irrespective of Vitamin K Status in a Rat Model of Chronic Kidney Disease with Hyperphosphatemia and Secondary Hyperparathyroidism $\mathbf{s}$
}

\author{
Kristin M. McCabe, Jason G. Zelt, Martin Kaufmann, Kimberly Laverty, Emilie Ward, \\ Henry Barron, Glenville Jones, Michael A. Adams, and Rachel M. Holden \\ Departments of Biomedical and Molecular Sciences (K.M.M., J.G.Z., M.K., K.L., E.W., H.B., G.J., M.A.A.) and Medicine \\ (G.J., R.M.H.), Queen's University, Kingston, Ontario, Canada
}

Received February 6, 2018; accepted May 11, 2018

\begin{abstract}
Patients with chronic kidney disease (CKD) have a markedly increased risk for developing cardiovascular disease. Nontraditional risk factors, such as increased phosphate retention, increased serum fibroblast growth factor 23 (FGF-23), and deficiencies in vitamins $\mathrm{D}$ and $\mathrm{K}$ metabolism, likely play key roles in the development of vascular calcification during CKD progression. Calcitriol $\left[1,25-(\mathrm{OH})_{2}-\mathrm{D}_{3}\right]$ is a key transcriptional regulator of matrix Gla protein, a vitamin $\mathrm{K}$-dependent protein that inhibits vascular calcification. We hypothesized that calcitriol treatment would inhibit the development of vascular calcification and this inhibition would be dependent on vitamin $\mathrm{K}$ status in a rat model of CKD. Rats were treated with dietary adenine $(0.25 \%)$ to induce CKD, with either 0,20 , or $80 \mathrm{ng} / \mathrm{kg}$ of calcitriol with low or high dietary vitamin K1 $(0.2$ or $100 \mathrm{mg} / \mathrm{kg})$ for 7 weeks. Calcitriol at
\end{abstract}

both lower (20 $\mathrm{ng} / \mathrm{kg})$ and moderate $(80 \mathrm{ng} / \mathrm{kg})$ doses increased the severity of vascular calcification, and contrary to our hypothesis this was not significantly improved by high dietary vitamin $\mathrm{K} 1$. Calcitriol had a dose-dependent effect on: 1) lowering serum parathyroid hormone, 2) increasing serum calcium, and 3) increasing serum FGF-23. Calcitriol treatment significantly increased aortic expression of the calcification genes Runx2 and Pit-1. These data also implicate impaired vitamin $\mathrm{D}$ catabolism in CKD, which may contribute to the development of calcitriol toxicity and increased vascular calcification. The present findings demonstrate that in an adenineinduced rat model of CKD calcitriol treatment at doses as low as $20 \mathrm{ng} / \mathrm{kg}$ can increase the severity of vascular calcification regardless of vitamin $\mathrm{K}$ status.

\section{Introduction}

Chronic kidney disease (CKD) affects approximately $13 \%$ of the Western population (Coresh et al., 2007; Hill et al., 2016). Patients with CKD have a marked increased risk of developing cardiovascular disease and are more likely to die of cardiovascular disease before ever requiring renal replacement therapy (Andrade and Ignaszewki, 2008). In addition to Framingham risk factors, CKD patients also have many nontraditional risk factors including disorders in calcium and phosphate metabolism, which lead to the development of vascular calcification (VC). VC occurs when calciumphosphate crystals deposit within the medial layer of the vasculature leading to an increase in vessel stiffness, a decrease in arterial compliance, and an increase in cardiovascular and all-cause mortality (London et al., 2003). Multiple studies have confirmed associations between the extent of VC and mortality in CKD patients (Guérin et al., 2001, 2006, 2008; London et al., 2001, 2003; Safar et al., 2002; Pannier

The authors acknowledge the financial support provided by the Heart and Stroke Foundation of Ontario, the Kidney Foundation of Canada, and the Canadian Institute of Health Research.

https://doi.org/10.1124/jpet.117.247270.

S This article has supplemental material available at jpet.aspetjournals.org. et al., 2005; Briet et al., 2006). Fibroblast growth factor 23 (FGF-23) is a hormone that regulates phosphate homeostasis and is also elevated in the early stages of CKD. Some studies also suggest that FGF-23 could be an independent risk factor for cardiovascular disease and mortality (Gutiérrez et al., 2008; Faul et al., 2011; Isakova et al., 2011).

Vitamin D also plays a key role in calcium/phosphate homeostasis, and it is well-recognized that vitamin D metabolism becomes impaired with the development of CKD. Circulating calcitriol $\left[1,25-(\mathrm{OH})_{2}-\mathrm{D}_{3}\right]$, the active vitamin $\mathrm{D}$ hormone, is derived from 25-OH-D ${ }_{3}$ via renal CYP27B1 and regulates calcium and phosphate homeostasis in concert with parathyroid hormone (PTH) and FGF-23 (Fig. 11A) (Crenshaw et al., 2011; Quarles, 2012). Many studies support the finding that, together, a loss of renal CYP27B1 activity (due to inhibition by FGF-23 and loss of renal mass) (Petkovich and Jones, 2011; Nigwekar et al., 2012) and a reduction in the levels of 25-OH-D (Nigwekar et al., 2012) lead to severe calcitriol deficiency. In addition, studies support upregulation of CYP24A1, the enzyme responsible for catabolism of $25-\mathrm{OH}-\mathrm{D}_{3}$ and $1,25-(\mathrm{OH})_{2}-\mathrm{D}_{3}$; however, the levels of these metabolites appear to be low, suggesting that vitamin $\mathrm{D}$ catabolism is dysregulated in CKD (Helvig et al., 2010; Jones et al., 2012). To the best of our knowledge, the impact of calcitriol therapy on the 
upregulation of CYP24A1 and catabolism of vitamin D substrates has not been studied in a CKD model.

There remains considerable debate regarding the safety of vitamin $\mathrm{D}$ treatment in this population. A number of clinical studies have found that treating patients with vitamin D receptor activators, such as calcitriol $\left[1,25-(\mathrm{OH})_{2}-\mathrm{D}_{3}\right]$, versus no treatment provides a survival advantage for early stage CKD and end-stage kidney disease patients (Teng et al., 2003, 2005; Melamed et al., 2006; Tentori et al., 2006; Levin et al., 2008; Naves-Díaz et al., 2008; Wolf et al., 2008; Nigwekar et al., 2012). However, despite these data, treatment of CKD patients with calcitriol is primarily directed at targeting specific PTH levels. This hesitation to treat CKD patients with calcitriol may be a consequence of a number of studies in vitro and in animal models of CKD that suggest calcitriol promotes VC (Inagaki et al., 1995; Haffner et al., 2005; Henley et al., 2005; Wu-Wong et al., 2006b; Terai et al., 2009). However, emerging preclinical data suggest that treatment with lower doses of calcitriol can inhibit VC (Mathew et al., 2008; Lau et al., 2012). One explanation is that calcitriol alters vascular susceptibility to calcification in a dose- and microenvironment-dependent manner, where decreases and increases beyond the optimal therapeutic window promote VC (Razzaque, 2011; Rodriguez et al., 2011).

Calcitriol is a known transcriptional regulator of matrix Gla protein (MGP) in vascular smooth muscle cells (Farzaneh-Far et al., 2001; Proudfoot and Shanahan, 2006), bone cells (Fraser et al., 1988), and kidney (Fu et al., 2008). MGP is a vitamin $\mathrm{K}$-dependent protein and a potent inhibitor of VC (Luo et al., 1997). The $\gamma$-carboxylation of five Gla domains by the enzyme $\gamma$-glutamyl carboxylase, which requires vitamin $\mathrm{K}$ as a cofactor, is critical to the calcium binding function of MGP (Krueger et al., 2009; Holden et al., 2012). Marked MGP upregulation has been demonstrated in vivo in the aortas of animals with experimental CKD (Sweatt et al., 2003; Lomashvili et al., 2011), although the increase is of the inactive form of MGP when there is insufficient vitamin $\mathrm{K}$-mediated carboxylation. In vivo, calcitriol-induced VC is markedly enhanced in vitamin $\mathrm{K}$-deficient states (e.g., warfarin therapy) (Price et al., 2000). Our group has demonstrated that long-term treatment with a vitamin $K$ antagonist, warfarin, is independently associated with greater severity of aortic valve calcification in dialysis patients, and this effect was shown to be amplified in those subjects also taking calcitriol (Holden et al., 2007). Taken together, there may be important interactions between calcitriol and vitamin $\mathrm{K}$ status in the development and progression of VC. The data thus far support the hypothesis that calcitriol upregulates the expression of the key calcification inhibitor MGP; however, this requires sufficient vitamin $\mathrm{K}$ status to fully carboxylate and thus activate its anticalcification properties. The primary objective of this study was to determine in an animal model of CKD if calcitriol could inhibit VC and if this inhibition was dependent on adequate vitamin $\mathrm{K}$ status. The secondary objective was to determine the impact of calcitriol treatment on vitamin $\mathrm{D}$ catabolism and phosphate/calcium homeostasis in a rat model of CKD.

\section{Materials and Methods}

Experimental Animals. Male Sprague-Dawley rats (Charles River, St. Constant, Quebec, Canada) were individually housed in standard polypropylene cages and maintained on a 12-hour light-dark cycle. The animals used in this experiment were treated in accordance with the Canadian Council on Animal Care ethical guidelines of animal care, handling, and termination.

Treatment Groups. An animal model of CKD was employed, using dietary adenine as described previously (McCabe et al., 2013; Shobeiri et al., 2013) and a modified version of the adenine model described by Price et al. (2006). At the start of the experiments, normal Purina Rat Chow was exchanged with a specially formulated (but nutritionally balanced) diet (Harlan, Teklad, Madison, WI) on which the animals were maintained. The specially formulated diet contained either $0.25 \%$ adenine $(\mathrm{CKD})$ or $0 \%$ adenine (control) along with $1 \%$ phosphate, $1 \%$ calcium, $0.2 \mathrm{mg} / \mathrm{kg}$ vitamin $\mathrm{K} 1$ (low vitamin $\mathrm{K} 1$ ), $1 \mathrm{IU} / \mathrm{g}$ vitamin $\mathrm{D}$, and 6\% protein. Male Sprague-Dawley rats (beginning at 14 weeks of age) were divided into groups receiving either $0.25 \%$ adenine (CKD) or no adenine (control). Serum creatinine levels were measured after 3 weeks and animals were stratified into one of five treatment groups to ensure each group had equivalent kidney dysfunction. For the next 4 weeks, animals were maintained on their CKD diet with either 0,20 , or $80 \mathrm{ng} / \mathrm{kg}$ body weight calcitriol maintained on low vitamin K1, or 20 and $80 \mathrm{ng} / \mathrm{kg}$ calcitriol with the addition of high dietary vitamin $\mathrm{K} 1,100 \mathrm{mg} / \mathrm{kg}$ (Fig. $1, n=8$ /group, $N=40$ ). An additional group of eight rats was maintained on a control diet (no adenine). Weights and food intake were monitored on a daily basis, and animals were supplemented with normal chow and/or Nutri-Cal if their weight loss reached $10 \%$. There is no vitamin $\mathrm{K}$ or calcitriol in Nutri-Cal. The high vitamin $\mathrm{K} 1$ dose (100 $\mathrm{mg} / \mathrm{kg}$ of diet) was selected based on previous work that demonstrated this dose of $\mathrm{K} 1$ blunted the development of VC in an adenine-induced rat model of CKD (McCabe et al., 2013; Kaesler et al., 2014). The low vitamin $\mathrm{K}$ dose $(0.2 \mathrm{mg} / \mathrm{kg})$ was chosen to create a mild deficiency state while maintaining coagulation and was based on previous work (Carrié et al., 2004; Booth et al., 2008; McCabe et al., 2013; Shobeiri et al., 2013). At euthanasia, approximately $6 \mathrm{ml}$ of blood was drawn using a $22 \mathrm{~g}$ hypodermic needle inserted into the left ventricle of the heart while the animal was under isoflurane-induced anesthesia. Blood samples were spun $\left(4^{\circ} \mathrm{C}, 4000 \mathrm{~g}, 20\right.$ minutes $)$ using a BHG Hermle Z320K refrigerated centrifuge (Mandel Scientific Company Inc., Gosheim, Germany). The following tissues were collected, cleaned, and weighed: liver, kidneys, thoracic aorta, abdominal aorta, and various arteries (renal, superior mesenteric, iliac, and carotid). Tissues were collected and snap frozen in liquid nitrogen and stored at $-80^{\circ} \mathrm{C}$ for further analysis. A portion of the kidney, liver, and thoracic aorta was also collected and stored in RNAlater storage solution (Life Technologies, Thermo Fisher Scientific Inc., Waltham, MA) and stored at $-20^{\circ} \mathrm{C}$ until further analysis.

Serum Analysis. Serum creatinine levels were measured using QuantiChrom Creatinine Assay Kit (DICT-500) (BioAssay Systems, Hayward, CA) according to the manufacturer's instructions. Serum phosphate was measured using the malachite green method as described by Heresztyn and Nicholson (2001). Serum calcium was measured using the $O$-cresolphthalein complexone method (Sigma St. Louis, MO) described previously (McCabe et al., 2013). Serum PTH levels were assessed using a rat intact PTH ELISA Kit (Immutopics, Inc. San Clemente, CA) according to the manufacturer's instructions. Serum concentrations of C-terminal FGF-23 were assessed using a Rat FGF-23 (C-term) ELISA Kit (Immutopics, Inc.) according to the manufacturer's instructions.

25-OH-D ${ }_{3}, 24,25-(\mathrm{OH})_{2}-\mathrm{D}_{3}, 1,25-(\mathrm{OH})_{2}-\mathrm{D}_{3}$, and 1,24,25-(OH) ${ }_{3}-\mathrm{D}_{3}$. Serum $25-\mathrm{OH}-\mathrm{D}_{3}, 24,25-(\mathrm{OH})_{2}-\mathrm{D}_{3}, 1,25-(\mathrm{OH})_{2}-\mathrm{D}_{3}$, and $1,24,25-$ $(\mathrm{OH})_{3}-\mathrm{D}_{3}$ were measured using liquid chromatography-tandem mass spectrometry on a Waters BEH-C18 column $(1.7 \mu \mathrm{m}, 2.1 \times 50)$ and a Waters Acquity-Xevo-TQ-S (Waters Limited, Mississauga, ON, Canada) in multiple reactions monitoring mode (with a $\mathrm{MeOH} / \mathrm{H}_{2} \mathrm{O}$ gradient system) as described elsewhere (Kaufmann et al., 2014), with some modifcations for $1,25-(\mathrm{OH})_{2} \mathrm{D}_{3}$ and $1,24,25-(\mathrm{OH})_{3} \mathrm{D}_{3}$. For measurement of $1,25-(\mathrm{OH})_{2} \mathrm{D}_{3}$ and $1,24,25-(\mathrm{OH})_{3} \mathrm{D}_{3}, 150 \mu \mathrm{l}$ of serum was

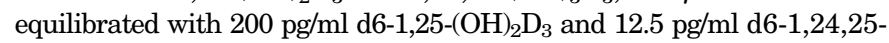
$(\mathrm{OH})_{3} \mathrm{D}_{3}$ internal standard. The sample was incubated with $100 \mu \mathrm{l}$ 


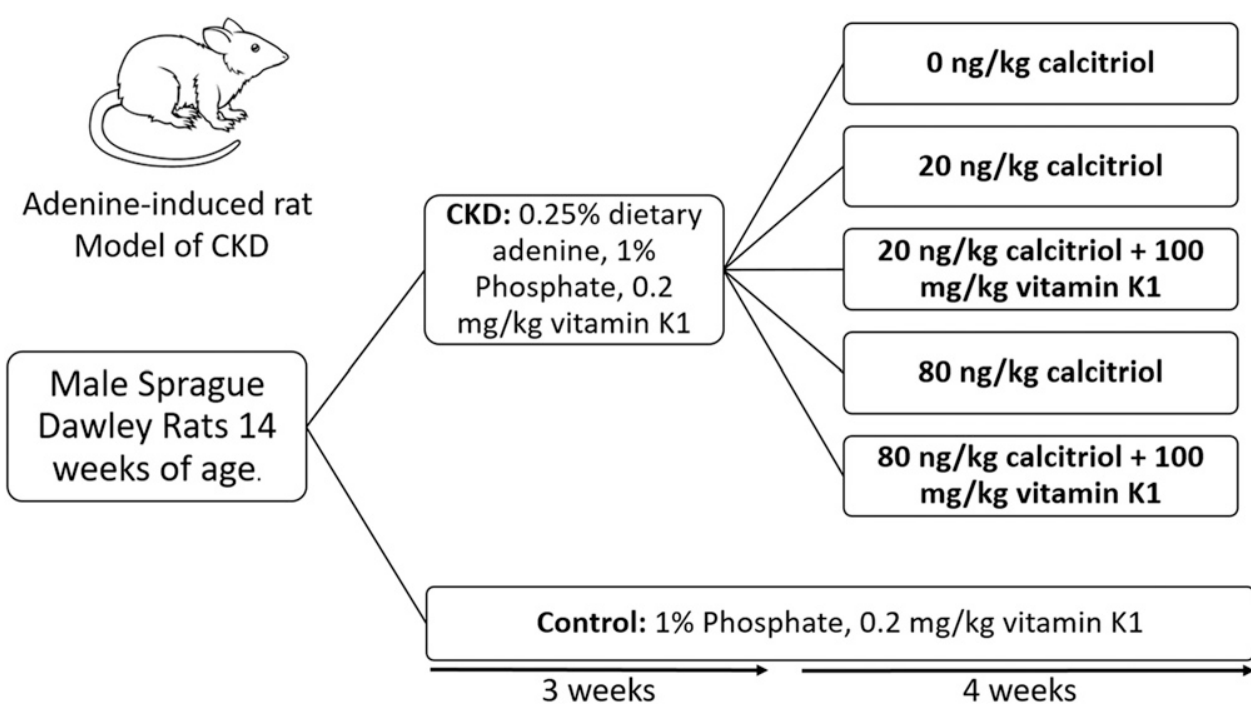

Fig. 1. A graphical description of the experimental outline. of anti-1,25- $(\mathrm{OH})_{2} \mathrm{D}_{3}$ antibody slurry (Immundiagnostik, Bensheim, Germany) for 2 hours at room temperature with orbital shaking at $1200 \mathrm{rpm}$. The slurry was isolated by vacuum filtration and rinsed with $4 \mathrm{X} 400 \mu \mathrm{l}$ of water, and vitamin D metabolites were eluted with $2 \mathrm{X} 200 \mu \mathrm{l}$ of ethanol. The eluate was dried and derivatized with 4-[2-(6,7-dimethoxy-4-methyl-3-oxo-3,4-dihydroquinoxalyl) ethyl]-1,2,4-triazoline-3,5-dione (DMEQ-TAD) as previously described (Kaufmann et al., 2014). The sample was redissolved in $50 \mu \mathrm{l}$ $50 / 50$ (percentage by volume) methanol/water and $35 \mu \mathrm{l}$ was injected into the liquid chromatography-tandem mass spectrometry system as previously described (Kaufmann et al., 2017). The multiple reactions monitoring transitions used for analysis of $1,25-(\mathrm{OH})_{2} \mathrm{D}_{3}$ and $1,24,25-(\mathrm{OH})_{3} \mathrm{D}_{3}$ were $\mathrm{m} / z 762>468+762>484$ and $\mathrm{m} / \mathrm{z}$ $778>468+778>484$, respectively. Quantification was based on a six-point calibrator generated in-house containing $5-300 \mathrm{pg} / \mathrm{ml}$ $1,25-(\mathrm{OH})_{2} \mathrm{D}_{3}$ and $1-25 \mathrm{pg} / \mathrm{ml} 1,24,25-(\mathrm{OH})_{3} \mathrm{D}_{3}$.

Hemodynamic Measurements. Pulse wave velocity was assessed using the foot-to-foot method as described by Essalihi et al. (2003) and modified as described previously (McCabe et al., 2013). Systolic blood pressure, diastolic blood pressure, as well as pulse pressure were calculated in the Chart program using the carotid catheter.

Vessel Calcium and Phosphorus Content. Vessels (thoracic aorta, abdominal aorta, and renal, superior mesenteric, iliac, and carotid arteries) were thawed, weighed, and homogenized in $1 \mathrm{~N}$ hydrochloric acid for 24 hours at $4^{\circ} \mathrm{C}$. The samples were spun, and the calcium content was determined using the $O$-cresolphthalein complexone method (Sigma) as described previously (McCabe et al., 2013) and the phosphate levels were determined using the malachite green method as described by Heresztyn and Nicholson (2001).

Real-Time Polymerase Chain Reaction. At time of sacrifice, sections of kidney, liver, and thoracic aorta were collected and stored in RNAlater storage solution (Life Technologies, Thermo Fisher Scientific Inc.) according to the manufacturer's instructions and stored at $-20^{\circ} \mathrm{C}$ until further analysis. Total RNA was extracted using the RNeasy Plus Universal Kit (Qiagen, Inc. Toronto, ON, Canada) and purity and concentration were confirmed using an eukaryote total RNA nano chip on an Agilent 2100 Bioanalyzer (Agilent Technologies Inc. Santa Clara, CA; an instrument run by the department of Pathology, Queen's University). Complimentary DNA was generated using the high-capacity cDNA reverse transcription kit (Life Technologies, Thermo Fisher Scientific Inc.) according to the manufacturer's instructions and stored at -20 until further analysis. The primers used for quantitative polymerase chain reaction are shown in Supplemental Table 1. Quantitative polymerase chain reaction was carried out on a CFX96 Real-Time System (Bio-Rad
Laboratories Inc. Montreal, QC, Canada) using SYBR Select Master Mix for CFX according to the manufacturer's instructions.

Von Kossa Method of Visualizing Vascular Calcification. The arteries were fixed in 10X neutral phosphate-buffered saline with $4 \%$ paraformaldehyde and embedded in paraffin blocks. Sections (3 to $4 \mu \mathrm{m}$ ) were stained for calcification using Von Kossa's method (Proudfoot et al., 1998, 2000) as described previously (McCabe et al., 2013). Areas of calcification appeared as dark brown regions in the medial wall of the artery.

Statistical Analysis. To analyze correlations between parameters, stepwise linear regression analysis was performed. The quantitative polymerase chain reaction data are presented as mean \pm S.E.M., all other data are presented as mean \pm S.D. Data were compared using one-way analysis of variance followed by Newman-Keuls post hoc test for $>2$ groups. Given that the distribution of calcium content within the vessels was not normal, log transformation was performed prior to statistical analysis. Analysis was performed using GraphPad Prism version 5 (GraphPad Software, San Diego, CA).

\section{Results}

Progression of Adenine-Induced CKD and Serum Biochemistry. CKD animals were treated with $0.25 \%$ dietary adenine for a total of 7 weeks. Animals were sampled at baseline and after 3,5, and 7 weeks for serum creatinine and phosphate (Fig. 2, A and B). Rats were treated with 0,20 , or $80 \mathrm{ng} / \mathrm{kg}$ calcitriol with low vitamin $\mathrm{K} 1$, and 20 or $80 \mathrm{ng} / \mathrm{kg}$ calcitriol with high vitamin K1 (100 mg/kg). Serum creatinine was elevated in all CKD groups compared with control after 3 (3-fold), 5 (7-fold), and 7 (7-fold) weeks (Fig. 2A). Serum phosphate was also elevated at 3 (1.2-fold), 5 (1.8-fold), and 7 (2.1-fold) weeks of CKD compared with control (Fig. 2B). There was no difference in serum creatinine or serum phosphate at any time point within the different CKD treatment groups.

After 7 weeks, CKD rats with $0 \mathrm{ng} / \mathrm{kg}$ calcitriol had similar levels of serum calcium to control (Fig. 3A). Serum calcium was significantly elevated with the calcitriol $20 \mathrm{ng} / \mathrm{kg}$ (1.1-fold) and $80 \mathrm{ng} / \mathrm{kg}$ (1.2 fold) doses (Fig. 3A). Serum phosphate was elevated in all CKD groups compared with control with no differences between calcitriol doses (2.3-fold for all groups) (Fig. 3B). Serum PTH was elevated 10 -fold in CKD $0 \mathrm{ng} / \mathrm{kg}$ compared with control (Fig. 3C) 

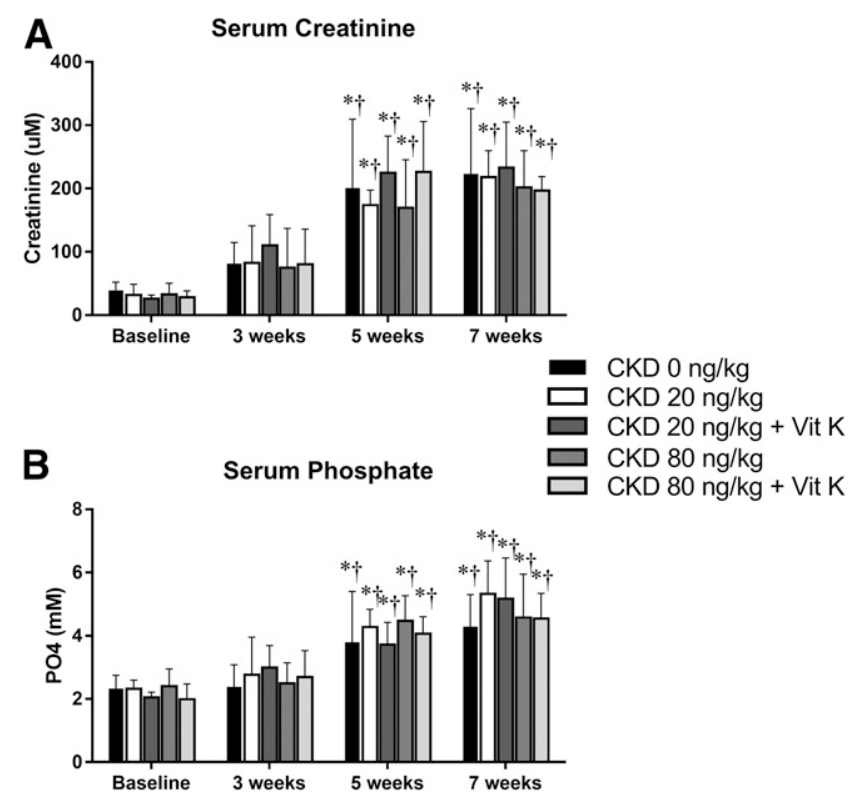

Fig. 2. Time course of serum creatinine (A) and phosphate (B) of rats given a $0.25 \%$ adenine diet for a total of 7 weeks to induce $\mathrm{CKD}$. All rats were sampled for serum creatinine (A) and phosphate (B) at baseline and after 3,5 , and 7 weeks. Rats were treated with either 0 or $20 \mathrm{ng} / \mathrm{kg}$ calcitriol, or $80 \mathrm{ng} / \mathrm{kg}$ calcitriol with or without the addition of high dietary vitamin $\mathrm{K}$ (Vit K, $100 \mathrm{mg} / \mathrm{kg})$. The data are shown as mean \pm S.D. $(n=8 /$ group, $* P<0.05$ vs. baseline, $\uparrow P<0.05$ vs. 3 weeks).

and significantly decreased in a dose-dependent manner in response to calcitriol (Fig. 3C). Serum FGF-23 was elevated 83-fold in CKD $0 \mathrm{ng} / \mathrm{kg}$ compared with control $(163 \pm 115 \mathrm{RU} / \mathrm{ml})$ and was further elevated in a dosedependent manner in response to calcitriol $20 \mathrm{ng} / \mathrm{kg}$ (288-fold) and $80 \mathrm{ng} / \mathrm{kg}$ (859-fold) (Fig. 3D). There was no significant effect of high dietary vitamin K1 on any of these measures.

Vessel Calcification. CKD increased vessel calcification compared with control in the thoracic aorta, abdominal aorta, and the renal, carotid, iliac, and superior mesenteric arteries (Fig. 4). Calcitriol treatment alone at 20 and $80 \mathrm{ng} / \mathrm{kg}$ significantly increased vessel calcium content further in all vessels studied except for the superior mesenteric artery (Fig. 4). The addition of high dietary vitamin $\mathrm{K} 1$ to the $20 \mathrm{ng} / \mathrm{kg}$ calcitriol group returned the vessel calcium content to the levels of the $0 \mathrm{ng} / \mathrm{kg}$ calcitriol group in all of the vessels studied except for the superior mesenteric artery (Fig. 4). There was no effect of the addition of high dietary vitamin $\mathrm{K} 1$ to the $80 \mathrm{ng} / \mathrm{kg}$ calcitriol treatment.

Hemodynamic Consequences of Calcification. Pulse wave velocity was significantly elevated in CKD at both 20 and $80 \mathrm{ng} / \mathrm{kg}$ of calcitriol compared with control (Fig. 5A). Pulse pressure was significantly elevated in CKD at $20 \mathrm{ng} / \mathrm{kg}$ calcitriol compared with control, and further elevated at $80 \mathrm{ng} /$ $\mathrm{kg}$ calcitriol (Fig. 5B). There was no significant effect of the addition of high dietary vitamin $\mathrm{K} 1$ to the 20 or $80 \mathrm{ng} / \mathrm{kg}$ calcitriol treatment groups.

Effect of Hypercalcemia on Calcification. To determine if the calcitriol-induced hypercalcemia was associated with increased vessel calcification, we compared the vessel calcium levels in animals with and without hypercalcemia (2.8 $\mu \mathrm{M}$ was chosen to reflect hypercalcemia because it was the upper $99 \%$ confidence interval of the mean of control serum calcium). There was no difference in vessel calcium levels between animals with or without serum hypercalcemia (Supplemental Fig. 1) and no correlation between serum calcium and vessel calcium (data not shown).
A

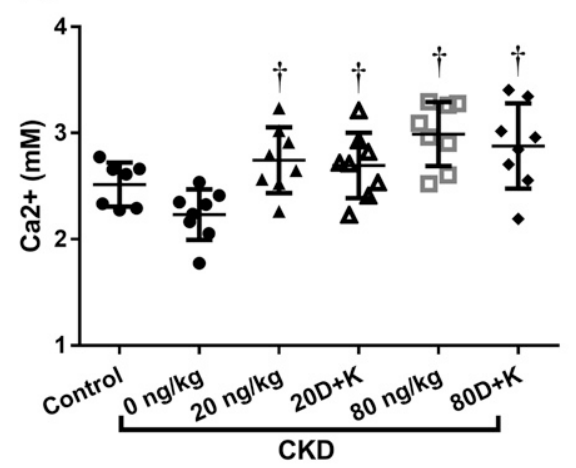

C

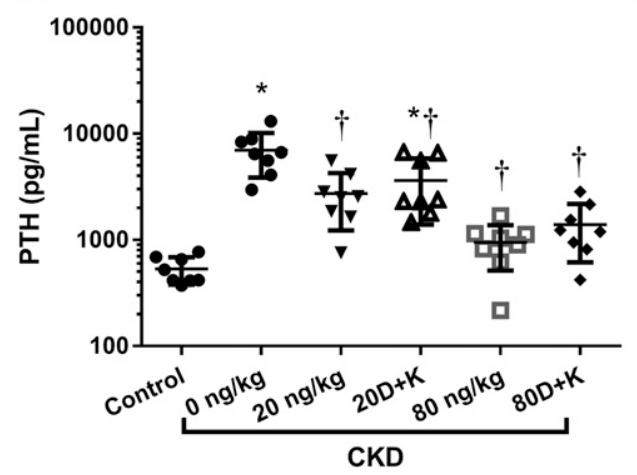

B

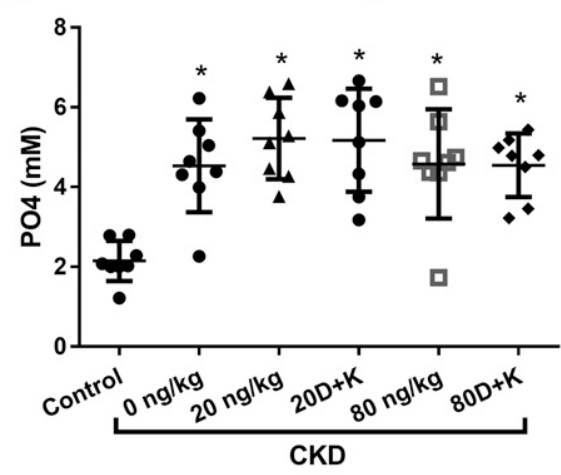

D

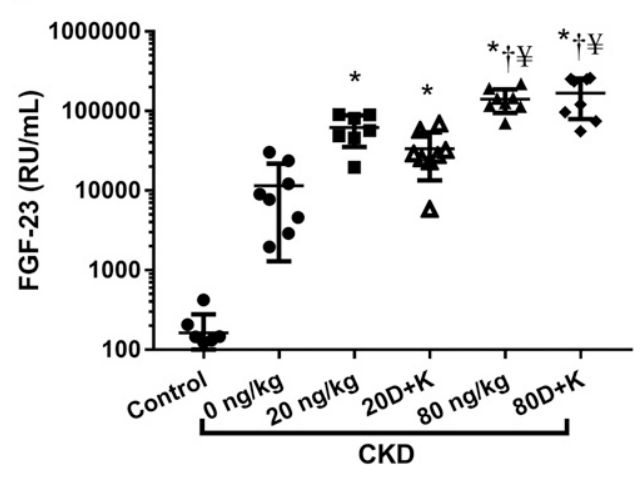

Fig. 3. Rats were given a $0.25 \%$ adenine diet for a total of 7 weeks to induce CKD or $0 \%$ adenine in control. Rats with CKD were treated with 0,20 , or $80 \mathrm{ng} / \mathrm{kg}$ calcitriol, with or without the addition of high dietary vitamin $\mathrm{K} 1 \quad(100 \mathrm{mg} / \mathrm{kg}$, $\mathrm{D}+\mathrm{K})$. Results are shown for serum calcium (A), phosphate (B), PTH (C), and FGF-23 (D). The data are shown as mean \pm S.D. ( $n=8$ /group), ${ }^{*} P<0.05$, vs. control, $\dagger P<0.05$ vs. CKD $0 \mathrm{ng} / \mathrm{kg}$, $¥ P<0.05$ vs. CKD $20 \mathrm{ng} / \mathrm{kg}$. 
A Thoracic Aorta

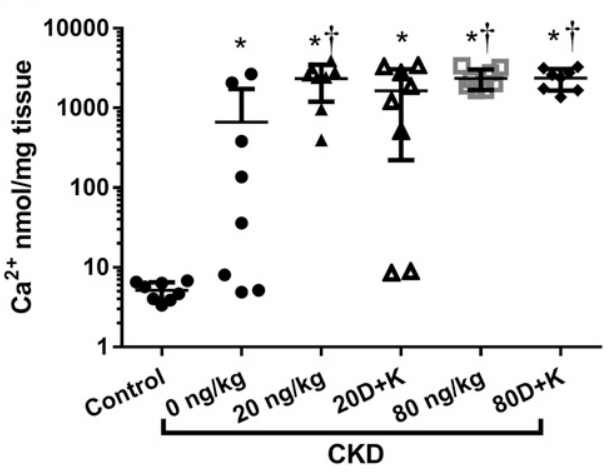

C

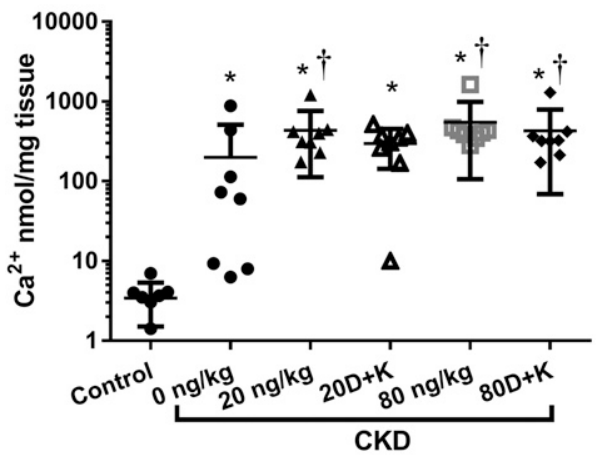

E

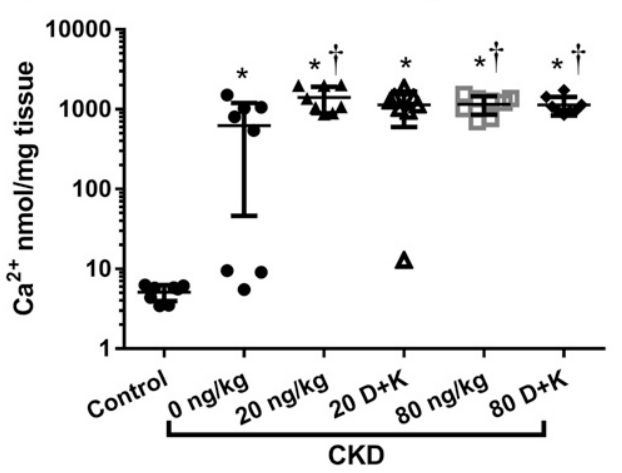

B Abdominal Aorta

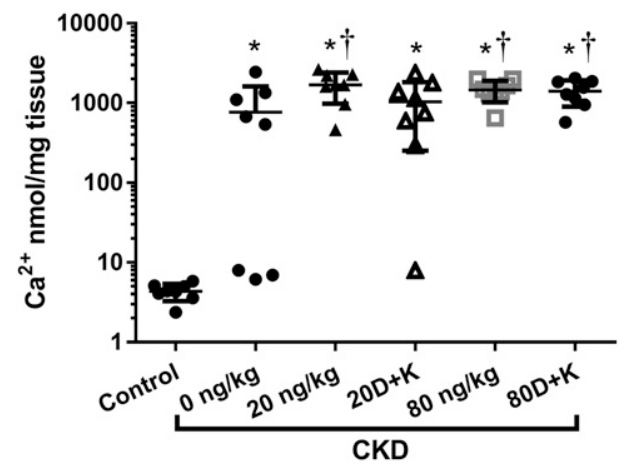

D

Carotid artery

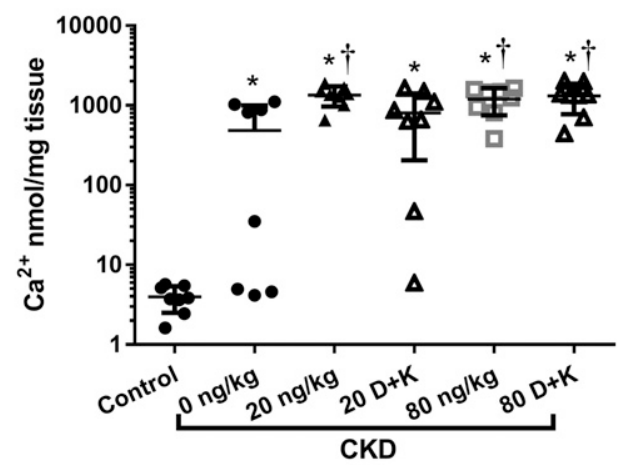

F Superior Mesenteric Artery

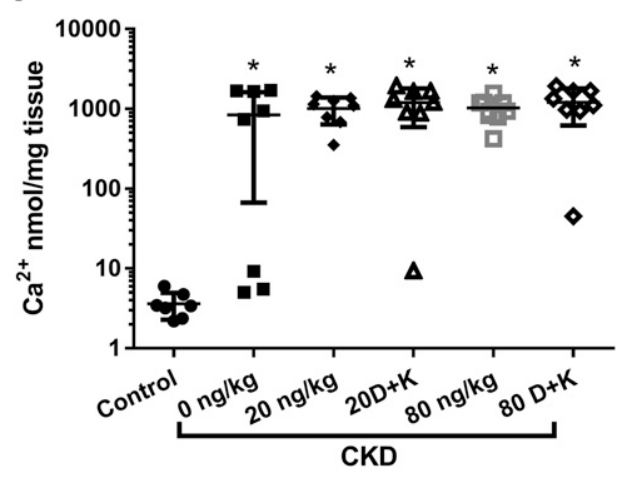

Fig. 4. Vessel calcium (nanomoles per milligram tissue) in thoracic aorta (A), abdominal aorta (B), renal artery (C), carotid artery (D), iliac artery (E), and superior mesenteric artery $(\mathrm{F})$ of rats given a $0.25 \%$ adenine diet for a total of 7 weeks to induce CKD and treated with 0,20 , or $80 \mathrm{ng} / \mathrm{kg}$ calcitriol, with or without the addition of high dietary vitamin $\mathrm{K}$ (100 $\mathrm{mg} / \mathrm{kg}$ vitamin $\mathrm{K} 1, \mathrm{D}+\mathrm{K})$. The data are shown as mean \pm S.D. $(n=8$ /group), $* P<0.05$ vs. control, $\uparrow P<0.05$ vs. CKD 0 ng $/ \mathrm{kg}$.
Expression of Calcification Genes. To investigate the mechanism of calcitriol-induced VC we looked at its effect on kidney and thoracic aorta gene expression, since these are two tissues known to calcify in adenine-induced CKD (Kaesler et al., 2014; McCabe et al., 2013), in control, CKD, and CKD $+80 \mathrm{ng} / \mathrm{kg}$ calcitriol animals (Figs. 6 and 7).
A

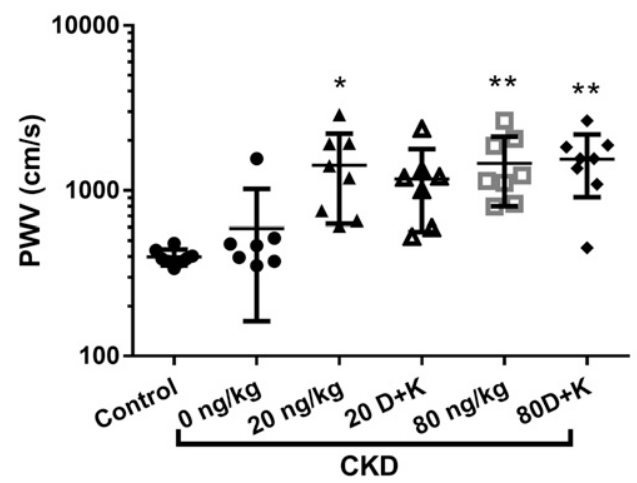

B

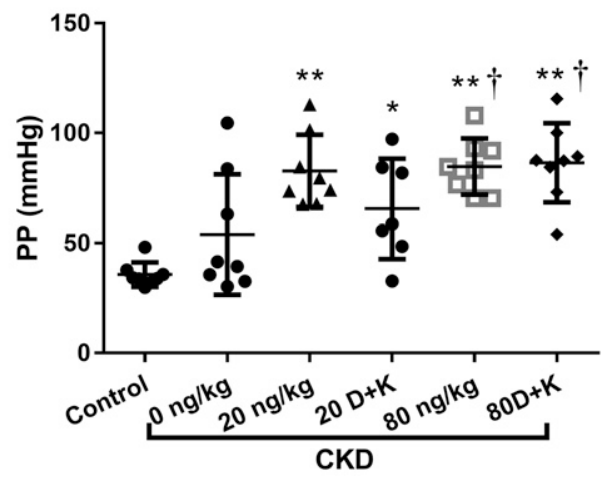

Fig. 5. Rats were given $0.25 \%$ dietary adenine for a total of 7 weeks to induce CKD or $0 \%$ adenine for control. CKD rats were treated with 0,20 , or $80 \mathrm{ng} / \mathrm{kg}$ calcitriol, with or without the addition of high dietary vitamin $\mathrm{K}(100 \mathrm{mg} / \mathrm{kg}$ vitamin K1, D + K). Pulse wave velocity (A) and pulse pressure (B) data are presented here. The data are shown as mean \pm S.D. ( $n=8$ /group), $* P<0.05 ; * * P<0.01$ vs. control, $\uparrow P<0.05$ vs. CKD $0 \mathrm{ng} / \mathrm{kg}$. 
A

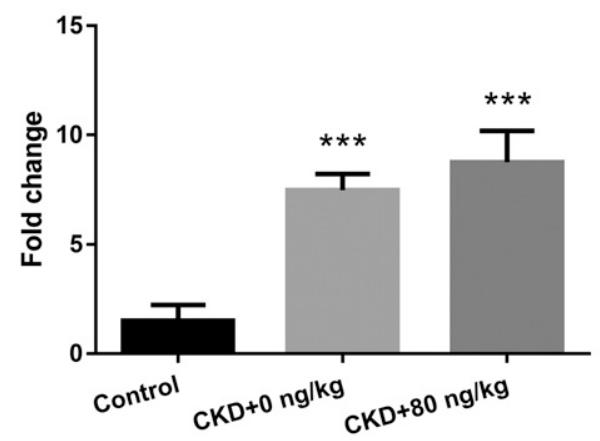

C

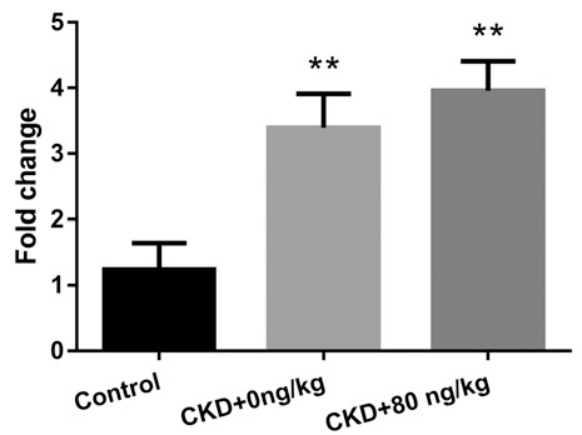

E

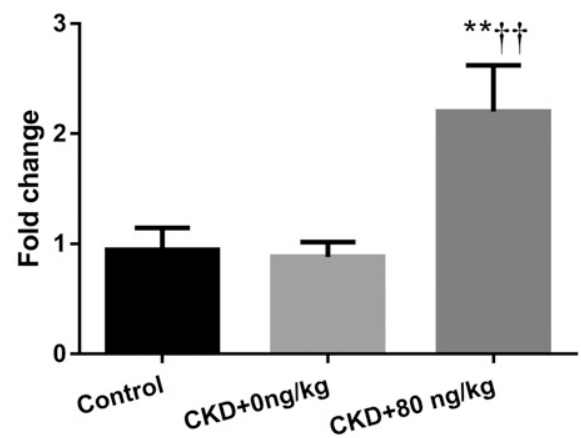

B

Kidney Pit1

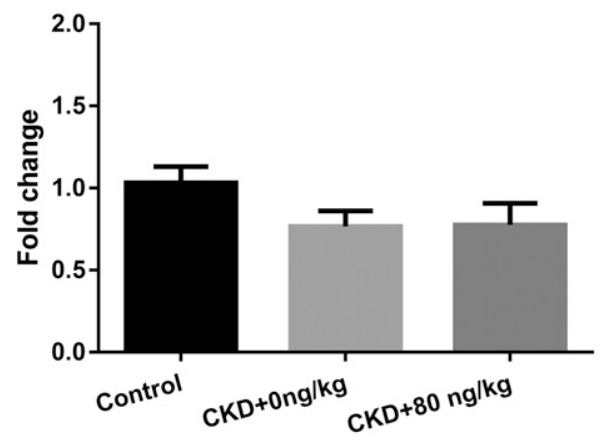

D

Kidney Bmp2

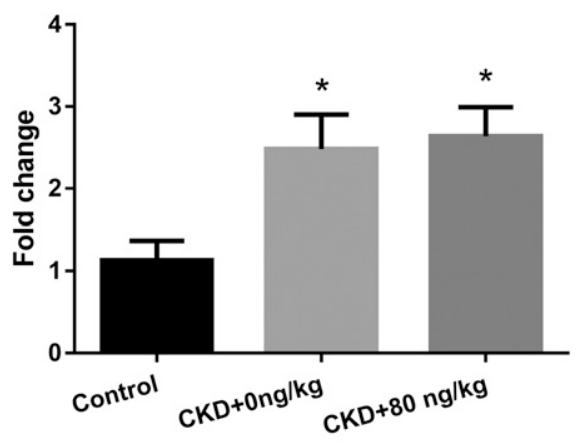

Fig. 6. Mgp (A), Pit1 (B), Runx2 (C), Bmp2 (D), Cyp24a1 (E), and Cyp27b1 (F) transcripts were assessed by quantitative polymerase chain reaction in the kidney of rats treated with $0 \%$ dietary adenine (control), $0.25 \%$ dietary adenine (CKD), or $0.25 \%$ dietary adenine and $80 \mathrm{ng} / \mathrm{kg}$ calcitriol (CKD $80 \mathrm{ng} / \mathrm{kg}$ ). Values are expressed as fold change vs. control rats normalized by beta-actin. The data are shown as mean \pm S.E.M. ( $n=6$-8/group) ${ }^{*} P<0.05$; ** $P<0.01$ vs. control, $* * * P<0.001$ vs. control $\dagger \dagger P<0.01$ vs. CKD.

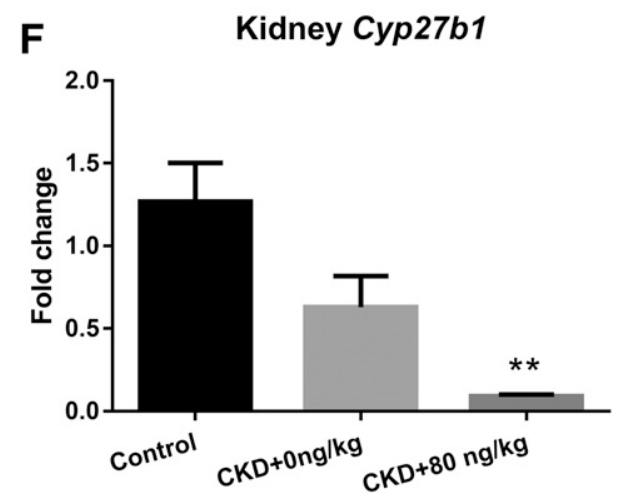

In CKD and CKD $+80 \mathrm{ng} / \mathrm{kg}$ calcitriol the kidney had significantly elevated levels of Mgp (7.5- and 8.8-fold, respectively), Runx2 (3.4- and 4.0-fold, respectively), and $B m p-2$ (2.5- and 2.6-fold, respectively) compared with control (Fig. 6, A, C, and D). There was no significant change in Pit-1 (Fig. 6B). Cyp24a1 expression increased 2.2-fold, while Cyp27b1 expression decreased to 0.1 -fold in response to calcitriol treatment (Fig. 6, E and F). Since the liver is not known to calcify in this model of CKD, we looked at liver expression as a negative control. Liver expression of these genes showed no changes in expression (Supplemental Fig. 2). In the thoracic aorta, calcitriol treatment in CKD $(80 \mathrm{ng} / \mathrm{kg})$ significantly increased the expression Pit-1 and Runx2 by 3-fold compared with control (Fig. 7).

Serum Vitamin D Metabolites. Serum vitamin D metabolites 25-OH-D $3,24,25-(\mathrm{OH})_{2}-\mathrm{D}_{3}, 1,25-(\mathrm{OH})_{2}-\mathrm{D}_{3}$, and $1,24,25-(\mathrm{OH})_{3}-\mathrm{D}_{3}$ were measured. The $25-\mathrm{OH}-\mathrm{D}_{3}$ levels were elevated in CKD $0 \mathrm{ng} / \mathrm{kg}$ (70\% increase) compared with control (Fig. 8A), and significantly decreased with calcitriol treatment at 20 and $80 \mathrm{ng} / \mathrm{kg}$ (Fig. 8A). Serum 24,25-(OH)$)_{2}-\mathrm{D}_{3}$ was decreased in CKD $0 \mathrm{ng} / \mathrm{kg}$ (40\% decrease) compared with control (Fig. 8B) and calcitriol treatment dose dependently further decreased $24,25-(\mathrm{OH})_{2}-\mathrm{D}_{3}$ at 20 and $80 \mathrm{ng} / \mathrm{kg}$ (Fig. 8B). $1,25-(\mathrm{OH})_{2}-\mathrm{D}_{3}$ was not detectable in $\mathrm{CKD}$ rats, and was increased in a dose-dependent manner by calcitriol treatment back to the level of control rats (Fig. 8C). 1,24,25-(OH) $)_{3}-\mathrm{D}_{3}$ was not detectable in any of the $\mathrm{CKD}$ groups, regardless of calcitriol treatment. The ratio of $25-\mathrm{OH}-\mathrm{D}_{3}: 24,25-(\mathrm{OH})_{2}-\mathrm{D}_{3}$ was elevated in CKD (approximately 2-fold) compared with control but there was no difference between calcitriol doses (Fig. 8E). There was no effect of vitamin $\mathrm{K}$ status on any of these measures. There was a significant linear relationship between serum $25-\mathrm{OH}-\mathrm{D}_{3}$ and $24,25-(\mathrm{OH})_{2}-\mathrm{D}_{3}$ for all groups (Fig. 8F), with the slope (rate of $25-\mathrm{OH}-\mathrm{D}_{3}$ metabolism to $\left.24,25-(\mathrm{OH})_{2}-\mathrm{D}_{3}\right)$ for control animals being significantly steeper than the slopes for all CKD groups $(P<0.05$, Fig. $8 \mathrm{~F})$.

Correlations with Serum FGF-23. Overall, as serum FGF-23 levels increased, vessel calcium levels also increased until a plateau was reached (Fig. 9, A-F). There was a significant correlation between FGF-23 and vessel calcium 


\section{A Thoracic Aorta Pit1 expression}

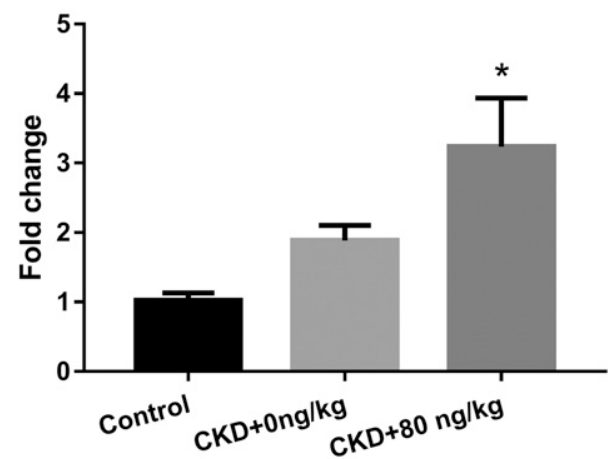

\section{Thoracic Aorta Runx2 expression}

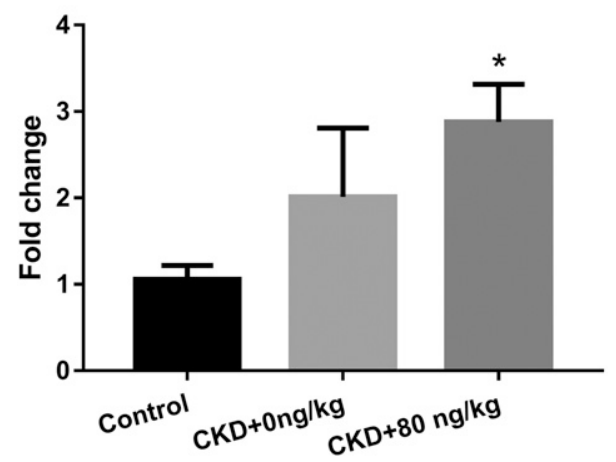

B Thoracic Aorta Bmp2 expression

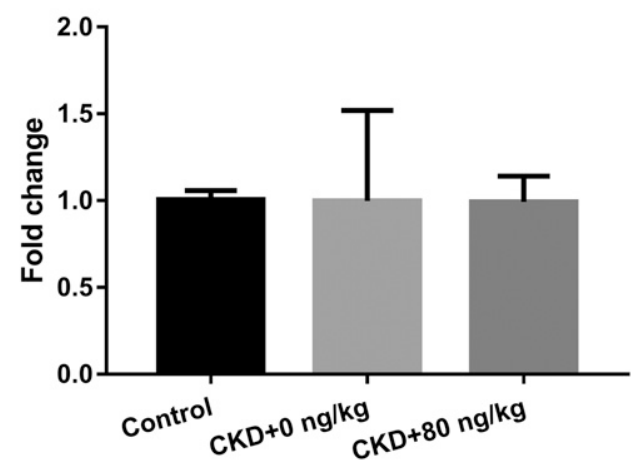

Fig. 7. Pit1 (A), Bmp2 (B), and Runx2 (C) transcripts were assessed by qPCR in the thoracic aorta of rats treated with $0 \%$ dietary adenine (control), $0.25 \%$ dietary adenine $(\mathrm{CKD}+0 \mathrm{ng} / \mathrm{kg})$, or $0.25 \%$ dietary adenine and $80 \mathrm{ng} / \mathrm{kg}$ calcitriol (CKD $+80 \mathrm{ng} / \mathrm{kg}$ ). Values are expressed as fold change vs. control rats normalized by beta-actin. The data are shown as mean \pm S.E.M. $(n=6-8$ /group). $* P<0.05$ vs. control. in $\mathrm{CKD} 0 \mathrm{ng} / \mathrm{kg}$ calcitriol $(P<0.05)$ in all vessels studied except for the superior mesenteric artery $\left(R^{2}=0.46,0.37\right.$, $0.32,0.25$, and 0.28 for the thoracic aorta, abdominal aorta, carotid, iliac, and renal arteries, respectively) (Fig. 9, A-F). The correlation between FGF-23 and vessel calcium content in the animals treated with 20 and $80 \mathrm{ng} / \mathrm{kg}$ of calcitriol was not significant (Fig. 9, A-F). There was also a significant positive correlation between serum FGF-23 and the ratio of $25-\mathrm{OH}-\mathrm{D}_{3}$ : $24,25-(\mathrm{OH})_{2}-\mathrm{D}_{3}\left(P<0.05, R^{2}=0.39\right)$, suggesting a decrease in 25-OH-D $\mathrm{D}_{3}$ metabolism at higher levels of FGF-23 (Fig. 9G). There was also a significant positive correlation between serum FGF-23 and serum calcium $\left(P<0.05, R^{2}=0.43\right)$ (Fig. 9H).

Von Kossa Staining. Sections of thoracic and abdominal aorta were stained for VC using the Von Kossa method, in which dark brown staining is indicative of phosphate in the crystals (Fig. 10). Staining confirmed the localization of the calcium-phosphate deposits in the vessel media (Fig. 10). There were some vessels that were positive for Von Kossa staining in the CKD group treated with $0 \mathrm{ng} / \mathrm{kg}$ calcitriol; however, in those treated with 20 or $80 \mathrm{ng} / \mathrm{kg}$ every vessel stained was Von Kossa positive (Fig. 10). No Von Kossa positive staining was found in any control animal (data not shown).

\section{Discussion}

Calcitriol, at both 20 and $80 \mathrm{ng} / \mathrm{kg}$ doses, increased the severity of $\mathrm{VC}$ and generated more severe hemodynamic consequences in this rat model of adenine-induced CKD. Contrary to our hypothesis, this effect of calcitriol was not significantly offset by high dietary vitamin K. Although MGP was upregulated in this model, calcitriol treatment was also associated with upregulation of procalcific genes in the thoracic aorta. Calcitriol had the expected dose-dependent therapeutic effect of lowering PTH toward control levels, yet it also resulted in hypercalcemia and a dose-dependent increase in FGF-23 levels, both of which may also contribute directly to VC. Calcitriol treatment restored $1,25-(\mathrm{OH})_{2}-\mathrm{D}_{3}$ in CKD animals to the levels observed in healthy animals; however, its metabolite, 1,24,25- $(\mathrm{OH})_{3}-\mathrm{D}_{3}$, was undetectable despite the upregulation of kidney Cyp24a1 by calcitriol treatment. Similarly, the slope between $25-\mathrm{OH}-\mathrm{D}_{3}$ and its key metabolite, 24,25- $(\mathrm{OH})_{2}-\mathrm{D}_{3}$, was less steep in CKD animals, indicating reduced metabolism. Taken together, these data suggest that despite the upregulation of Cyp24a1 transcription its enzymatic activity is impaired in this model. We propose that absent substrate catabolism may enhance tissue levels of 1,25- $(\mathrm{OH})_{2}-\mathrm{D}_{3}$ and promote off-target effects such as VC. This occurred even at the relatively low dose of calcitriol used in this experiment. The transcription of Pit-1, a key vascular smooth muscle phosphate transporter, was significantly upregulated in calcitriol-treated rats, providing a potential signaling pathway that could directly promote VC in concert with the impact of calcitriol on circulating levels of phosphate and calcium (see Fig. 11).

In this study, $20 \mathrm{ng} / \mathrm{kg}$ calcitriol significantly increased calcification compared with $0 \mathrm{ng} / \mathrm{kg}$; however, although the addition of high vitamin $\mathrm{K} 1$ to $20 \mathrm{ng} / \mathrm{kg}$ calcitriol lowered calcification levels such that they were no longer significantly greater than the $0 \mathrm{ng} / \mathrm{kg}$ group, it did not provide any further benefit. The lower calcitriol dose was chosen based on the consolidation of evidence from other experimental models (Mizobuchi et al., 2007; Mathew et al., 2008; Koleganova et al., 
A

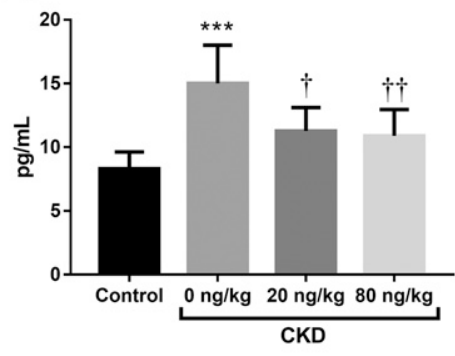

C

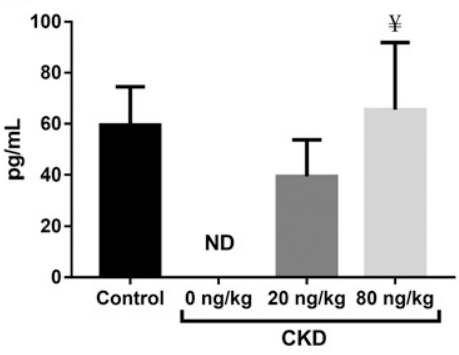

E

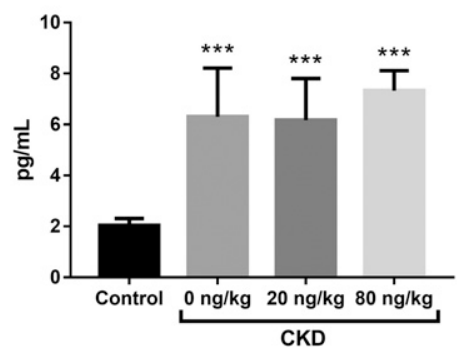

B

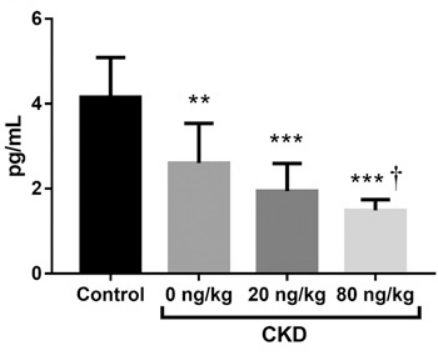

D

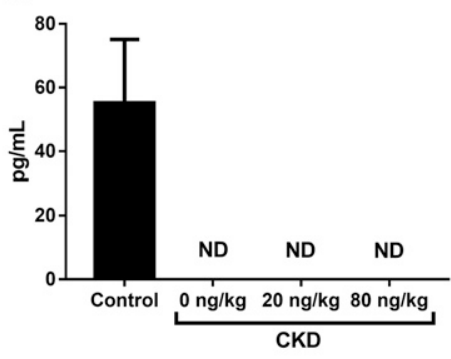

F $25-\mathrm{OH}-\mathrm{D}_{3}$ vs $24,25-(\mathrm{OH})_{2}-\mathrm{D}_{3}$

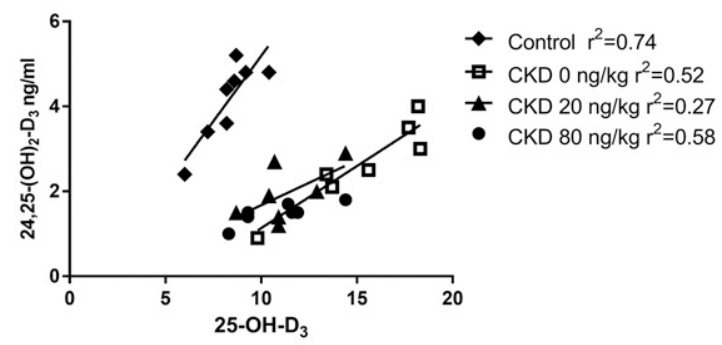

Fig. 8. Rats given a $0.25 \%$ adenine diet for a total of 7 weeks to induce CKD or $0 \%$ adenine for control. Rats with CKD were treated with 0,20 , or $80 \mathrm{ng} / \mathrm{kg}$ calcitriol. Results are shown for serum 25-OHD3 (A), 24,25-OH2-D3 (B), 1,25-OH2-D3 (C), 1,24,25-OH3-D3 (D), and the ratio of 25-OH-D:24,25-OH-D (E). Data are presented as mean \pm S.D., $n=8$ /group; $* * P<0.01, * * * P<0.001$ vs. control; $\dagger P<0.05, \dagger \dagger P<0.01$ vs. CKD $0 \mathrm{ng} / \mathrm{kg}$; $¥ P<0.05$ vs. CKD $20 \mathrm{ng} / \mathrm{kg}$. (F) Linear relationship between 25-OH-D and $24,25-\mathrm{OH}-\mathrm{D}(P<0.05, \mathrm{r} 2$ shown in graph).
2009; Terai et al., 2009; Lau et al., 2012). This $20 \mathrm{ng} / \mathrm{kg}$ dose has been shown to increase (Mizobuchi et al., 2007; Koleganova et al., 2009) or decrease (Mathew et al., 2008; Lau et al., 2012) VC in various kidney disease models. Two studies performed in a murine model of CKD showed that a daily dose of $20 \mathrm{ng} / \mathrm{kg}$ of calcitriol decreased calcification of atherosclerotic plaques (Mathew et al., 2008) and medial VC (Lau et al., 2012), respectively. In these murine studies, phosphate levels were elevated in CKD approximately 1.5-fold compared with control, and calcitriol treatment significantly decreased serum phosphate nearly back to control levels (Mathew et al., 2008; Lau et al., 2012) and consequently also decreased serum FGF-23 (Lau et al., 2012). However, in our study, serum phosphate was over 2 -fold elevated in all CKD groups and a significant increase in serum calcium and FGF-23 was observed in all calcitriol-treated rats. Phosphate and calcium are well-known initiators of VC (Block, 2001; Reynolds et al., 2004; Lau et al., 2010) and FGF-23 levels are associated with increased cardiovascular consequences (Parker et al., 2010; Seiler et al., 2010). It may be that the adenine-induced rat model produced more severe CKD and that the rat model is more susceptible to changes in serum phosphate/calcium in response to a high phosphate diet and/or calcitriol. Dialysis patients treated with calcitriol frequently experience hyperphosphatemia and hypercalcemia; therefore, these changes are similarly observed in humans and have been linked to VC in this population (Goldsmith et al., 1997; Guérin et al., 2001).
To examine whether the increased serum calcium was a key factor linked to the increased VC, we compared the severity of vessel calcification in rats with and without hypercalcemia and found that there was no difference in VC, suggesting that additional factors must be involved. This is consistent with previous research, which has reported that calcitriol can induce calcification in uremic and nonuremic rats without necessarily inducing changes in serum calcium and phosphate (Koleganova et al., 2009).

The transcription of MGP, a key local inhibitor of VC, is regulated by calcitriol. MGP was upregulated in response to the uremic environment but was not further upregulated significantly in response to calcitriol. The upregulation of MGP expression may have been near its maximum response in CKD (7.5-fold increase) and thus was not able to significantly increase any further in response to calcitriol (8.7-fold increase). Our original hypothesis that calcitriol at low doses would inhibit VC in the presence of a high vitamin $\mathrm{K}$ diet was based on presumed upregulation of MGP, which we did not observe. Ultimately, the severity of $\mathrm{VC}$ is determined by a balance between those factors that promote VC (e.g., hypercalcemia and hyperphosphatemia) and those that inhibit VC (e.g., MGP). Despite overall upregulation of MGP in the CKD rats there was no impact of calcitriol on MGP expression nor was there any interaction between calcitriol and vitamin $\mathrm{K}$ status with respect to the calcification outcome. Previous studies in this adenine model have shown that the identical dose of vitamin K attenuated VC (McCabe et al., 2013; Kaesler 

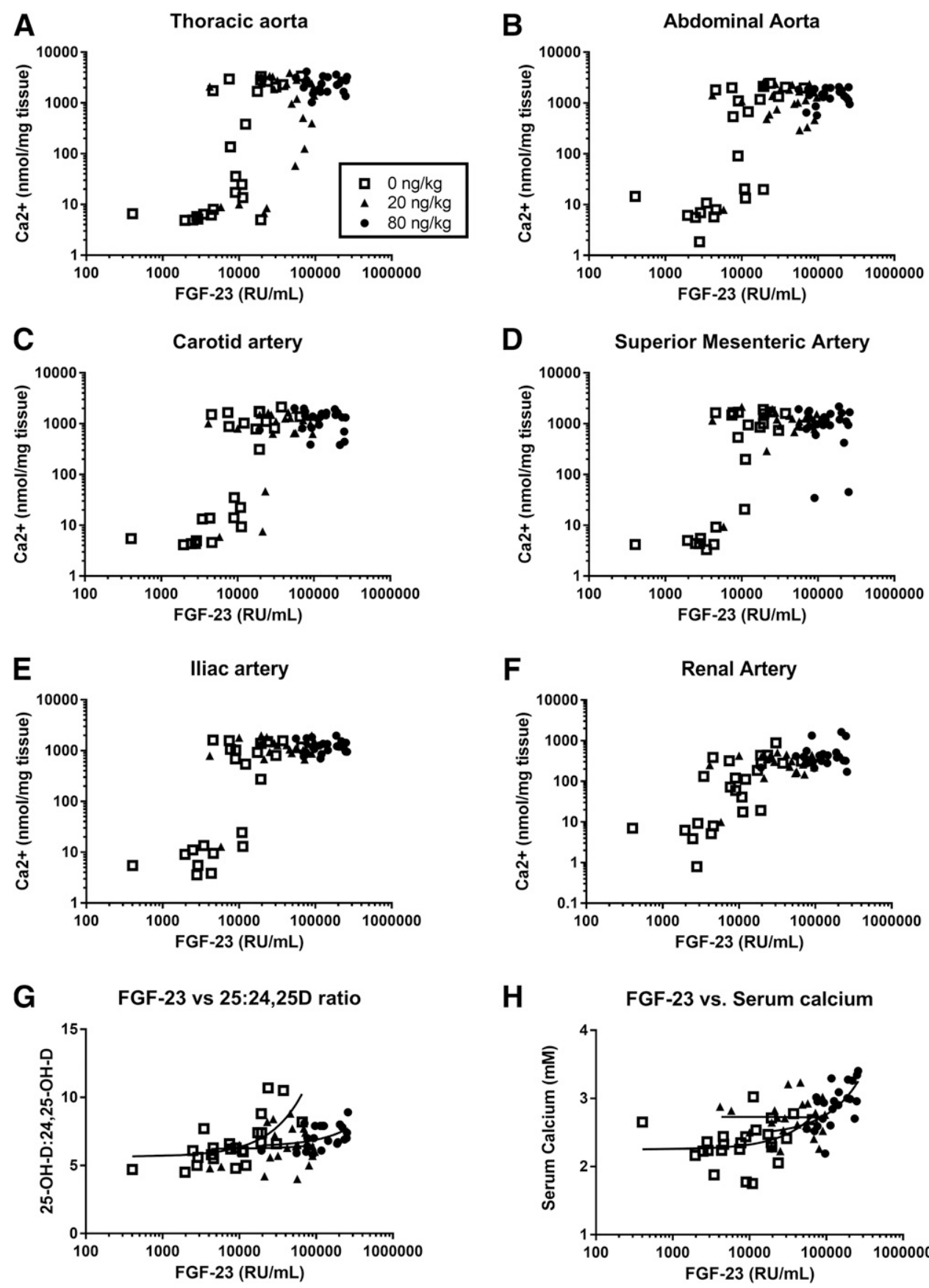

Fig. 9. Correlation between serum FGF23 on the $x$-axis and vessel calcium level on the $y$-axis in the thoracic aorta (A), abdominal aorta (B), carotid (C), superior mesenteric $(\mathrm{D})$, iliac $(\mathrm{E})$, and renal $(\mathrm{F})$ arteries and correlation between serum FGF-23 and the ratio of 25-OH-D:24,25$\mathrm{OH}-\mathrm{D}(\mathrm{G})$ and serum calcium $(\mathrm{H})$ in rats treated with $0.25 \%$ dietary adenine and either $0 \mathrm{ng} / \mathrm{kg}(\square), 20 \mathrm{ng} / \mathrm{kg}(\mathbf{\Delta})$, or $80 \mathrm{ng} /$ $\mathrm{kg}(\bullet)$ of calcitriol; $0 \mathrm{ng} / \mathrm{kg}$ correlations are significant in each artery except for the superior messenteric $(P<0.05)$. $n=22-24$ /group.

H

FGF-23 vs. Serum calcium

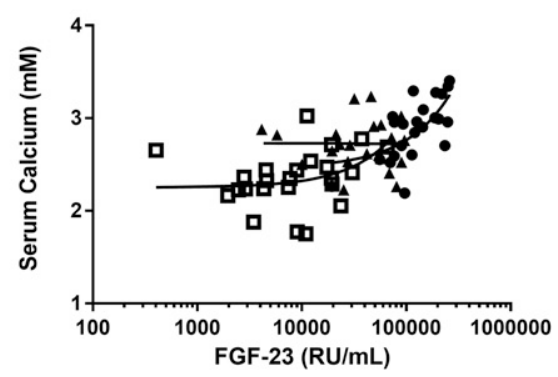

et al., 2014; Zaragatski et al., 2016); however, neither of these studies included calcitriol treatment and levels of serum calcium were not different from control animals. Furthermore, FGF-23 levels were significantly elevated in a dose-dependent manner in response to calcitriol treatment. Taken together, the inhibitory effect of adequate MGP carboxylation was not sufficient to surmount the adverse effects of calcitriol on the vasculature in this model of CKD.

It has been suggested that calcitriol has a direct effect within the vasculature and therefore may have broad implications in cardiovascular health (Jones, 2007). To further examine this, we looked at the expression of some key calcification regulating genes in response to calcitriol treatment. Runx2, a marker of osteogenic transformation, was upregulated in response to calcitriol in the thoracic aorta. There was also a significant impact of calcitriol treatment on the expression of Pit1 in the thoracic aorta, which was not observed in the kidney. PIT1 is a sodiumdependent phosphate transporter that is primarily responsible for phosphate uptake into vascular smooth muscle cells, an event that initiates the process of VC. These results indicate a direct effect of calcitriol treatment on the regulation of procalcific genes in vascular tissue and support the work of others (Mizobuchi et al., 2007; Koleganova et al., 2009) indicating that there may indeed be a tissue-specific response. Furthermore, a study by Wu-Wong et al. (2006a) looked at the effect of calcitriol on gene expression in human coronary artery smooth muscle cells. They found a total of 


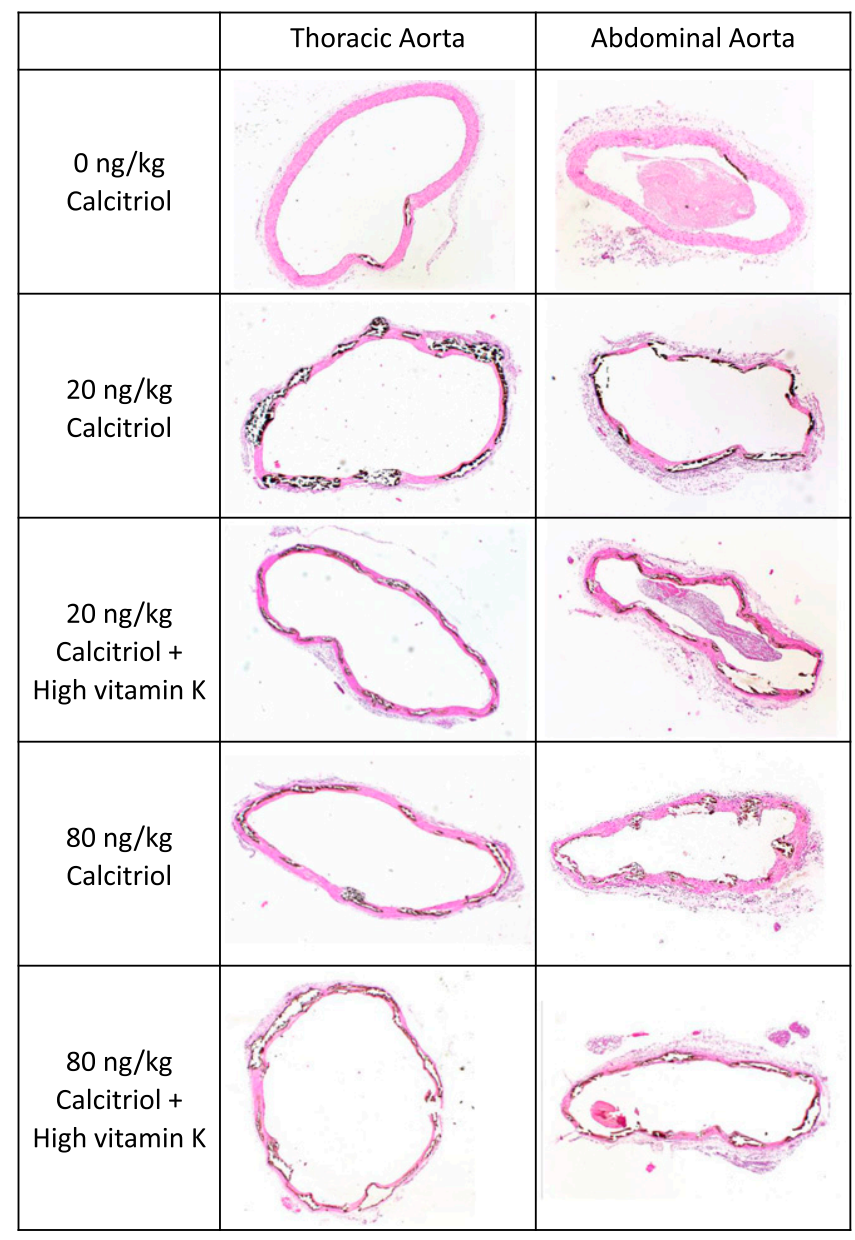

Fig. 10. Von Kossa stained blood vessels from animals treated with $0.25 \%$ dietary adenine along with low dietary vitamin $\mathrm{K} 1(0.2 \mathrm{mg} / \mathrm{kg}$ food $)$ or high dietary vitamin $\mathrm{K} 1$ (100 $\mathrm{mg} / \mathrm{kg}$ food) and 0,20 , or $80 \mathrm{ng} / \mathrm{kg}$ calcitriol. Positive staining (dark brown areas in vessel) denotes the region of calcification in the thoracic and abdominal aortas. All photographs were taken at the same magnification.

176 target genes of calcitriol; therefore, it is also possible that genes other than those measured here are implicated in development of $\mathrm{VC}$.

CYP24A1 is the major route of catabolism of both calcitriol $\left(1,25-(\mathrm{OH})_{2}-\mathrm{D}_{3}\right)$ and $25-\mathrm{OH}-\mathrm{D}_{3}$ into $1,24,25-(\mathrm{OH})_{3}-\mathrm{D}_{3}$ and $24,25-(\mathrm{OH})_{2}-\mathrm{D}_{3}$, respectively (Jones et al., 2012). The expression of Cyp24a1 in the kidney was similar in control and untreated CKD rats but was markedly upregulated in response to calcitriol (Helvig et al., 2010). Despite this, there was a significantly smaller increment in $24,25-(\mathrm{OH})_{2}-\mathrm{D}_{3}$ for a given increment in 25-OH-D $\mathrm{D}_{3}$ in $\mathrm{CKD}$ animals compared with controls, suggesting a decrease in $25-\mathrm{OH}-\mathrm{D}_{3}$ catabolism. Human data, pooled from five large cohort studies, similarly showed that the relationship between $24,25-(\mathrm{OH})_{2}-\mathrm{D}_{3}$ and 25-OH-D 3 was modified by eGFR, in which the slope became significantly less steep as kidney function declined (de Boer et al., 2014). Batacchi et al. (2017) also found that while vitamin $\mathrm{D}_{2}$ supplementation induces $1,25-(\mathrm{OH})_{2}-\mathrm{D}_{3}$ catabolism in control subjects this response is blunted in individuals with CKD. It was surprising that the $25-\mathrm{OH}-\mathrm{D}_{3}$ levels were higher in the $\mathrm{CKD}$ rats than in control animals since this finding is not typical for humans with CKD. The reasons for the higher levels of $25-\mathrm{OH}-\mathrm{D}_{3}$ in this experiment are unknown but could reflect severe abnormalities with 25-OH-D $\mathrm{D}_{3}$ catabolism and, therefore, accumulation in this model. CYP24A1 also metabolizes calcitriol, and despite restored levels of $1,25-(\mathrm{OH})_{2}-\mathrm{D}_{3}$ with calcitriol treatment the metabolite $1,24,25-(\mathrm{OH})_{3}-\mathrm{D}_{3}$ could not be detected in the CKD animals. These data support that CYP24A1 enzymatic function may be severely impaired in CKD. The absence of calcitriol catabolism may be a key factor contributing to calcitriol toxicity, which can be characterized by VC, hypercalcemia, and markedly elevated levels of FGF-23. FGF-23 inhibits activation of vitamin $\mathrm{D}$, and in a negative feedback manner active vitamin D stimulates FGF-23 (Wolf, 2010). There are potentially many off-target effects of FGF-23 that may be detrimental (Jüppner et al., 2010) and studies have shown that an elevated FGF-23 is associated with increased risk of cardiovascular events (Seiler et al., 2010; Kendrick et al., 2011) and mortality (Jean et al., 2009). In our study, there was a positive correlation between FGF-23 and VC in the CKD animals. Although FGF-23 has been implicated in the upregulation of CYP24, the ratio between $25-\mathrm{OH}-\mathrm{D}_{3}$ and 24,25- $(\mathrm{OH})_{2}-\mathrm{D}_{3}$ increased significantly with higher FGF-23 levels in all rats with CKD. Similarly, Dai et al. (2012) reported a correlation between higher FGF-23 levels and reduced 24,25- $(\mathrm{OH})_{2}-\mathrm{D}_{3}$ concentrations. Taken together, these data and the work of Dai et al. (2012) do not support FGF-23-mediated catabolism of vitamin D metabolites as has been suggested by others (Hasegawa et al., 2010; Helvig et al., 2010). One possibility is that $24,25-(\mathrm{OH})_{2}-\mathrm{D}_{3}$ is rapidly cleared to calcitroic acid in CKD. Measurement of the enzymatic activity of CYP24A1 within the kidney and further downstream metabolites would help resolve some of these uncertainties.

In summary, human studies indicate that low levels of serum calcitriol are associated with an increase in VC (Doherty et al., 1997; Watson et al., 1997), and patients treated with calcitriol to manage secondary hyperparathyroidism have an increased survival rate $(\mathrm{Wu}-\mathrm{Wong}$ et al., 2006b; Mathew et al., 2008; Terai et al., 2009; Razzaque, 2011). The ADVANCE study showed that calcimimetics with low-dose vitamin $\mathrm{D}$ sterols in dialysis patients was associated with less progression of coronary calcium score than patients taking greater doses of vitamin D sterols alone (Raggi et al., 2011; Ureña-Torres et al., 2013), suggesting that a combination of therapies may have a greater impact. Whether calcitriol treatment accelerates calcification remains controversial. In our experimental animal model of CKD, we found that 20 and $80 \mathrm{ng} / \mathrm{kg}$ doses of calcitriol clearly accelerated VC and its hemodynamic consequences and that this effect of calcitriol was not significantly modified by the underlying vitamin $\mathrm{K}$ status. Furthermore, these data implicate impaired vitamin D catabolism in CKD, which may contribute to the development of calcitriol toxicity. Further studies assessing CYP24A1 enzyme activity and the full profile of vitamin D metabolites are necessary to help explain these findings. This experiment is an example of the complexities of VC in chronic kidney disease. Phosphate, calcium, PTH, FGF-23, and direct vascular effects of calcitriol, along with other factors not analyzed in this study, including serum $\mathrm{Mg}^{2+}$ (ter Braake et al., 2018) and pyrophosphate (Lomashvili et al., 2014), may all independently contribute to $\mathrm{VC}$ and represent a complex interplay of factors that need to be 
A SKIN

7-Dehydrocholesterol

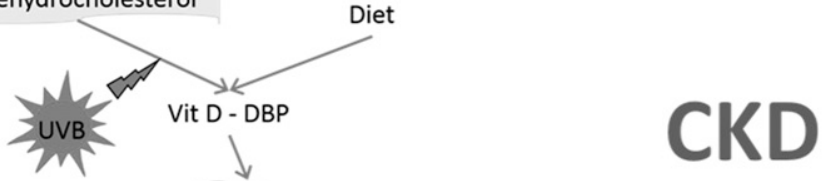

25-OHase
CYP 2R1 CYP24A1

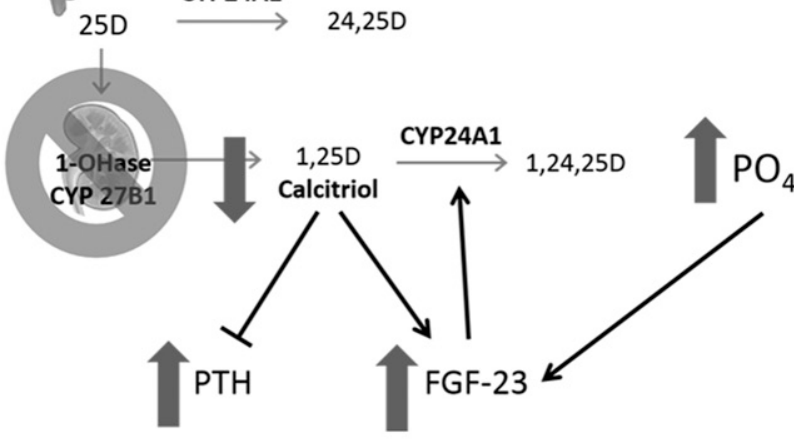

B

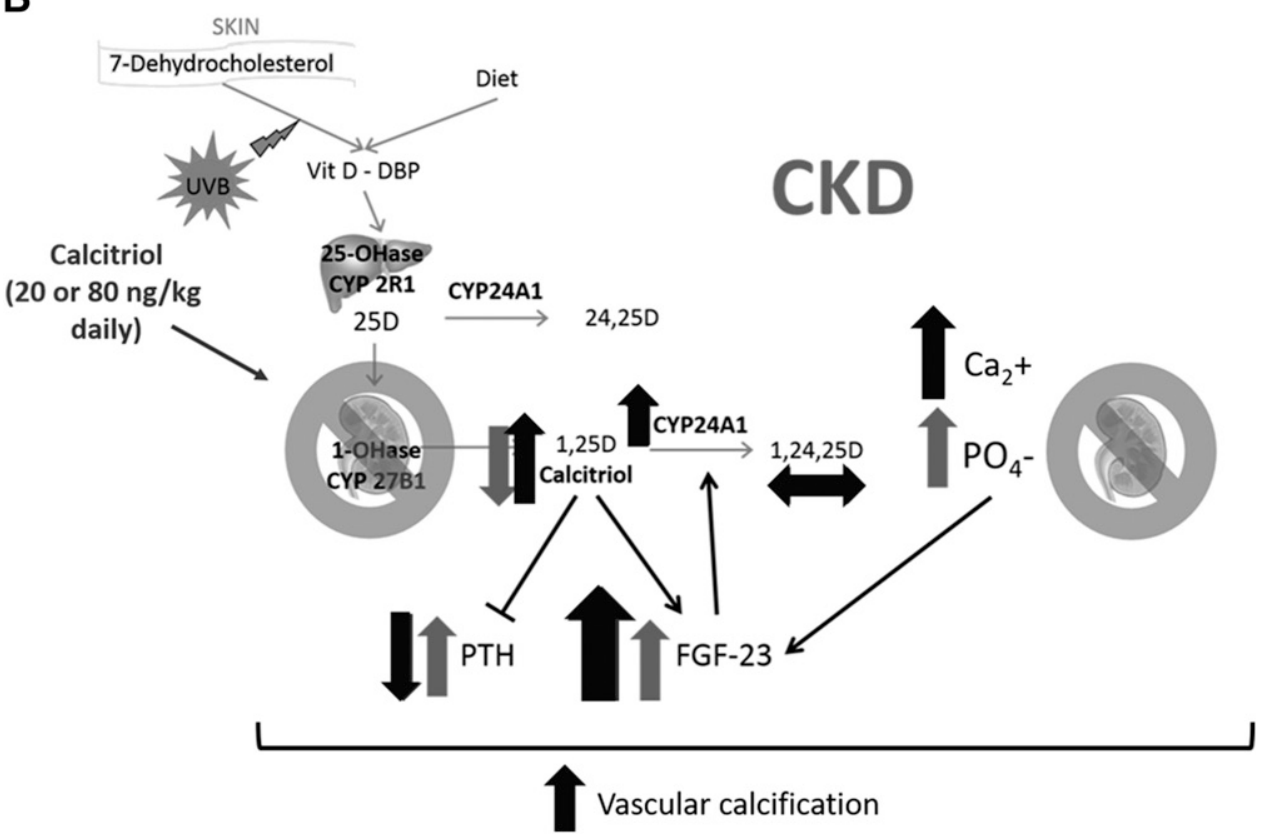

Fig. 11. Calcitriol metabolism in CKD. (A) Vitamin D, acquired either via the diet or via the sun, is hydroxylated to $25-\mathrm{OH}-\mathrm{D}_{3}$ in the liver by the enzymes CYP2R1 and CYP27A1 and then hydroxylated a second time primarily in the kidneys by CYP27B1 to $1,25-(\mathrm{OH})_{2}-\mathrm{D}_{3}$ (calcitriol), the active form. Calcitriol increases calcium and phosphate reabsorption and resorption in the small intestine and bone, respectively. It also increases FGF-23, a hormone that decreases phosphate reabsorption in the kidney, and in a negative feedback manner upregulates CYP24A1, which is the enzyme that metabolizes calcitriol. Patients with CKD have a deficiency in $1,25-(\mathrm{OH})_{2}-\mathrm{D}_{3}$ (calcitriol) due to loss of renal CYP27B1 with declining renal function and upregulation of the catabolic enzyme CYP24A1 by FGF-23. This decrease in 1,25- $(\mathrm{OH})_{2}-\mathrm{D}$ results in secondary hyperparathyroidism, which activates FGF-23 and, in turn, further inhibits renal CYP27B1. Despite high FGF-23 levels, further decline in renal function leads to a decrease in phosphate excretion and, therefore, an increase in circulating phosphate. The end result is a 1,25-OH-D ${ }_{3}$-deficient, high-PTH, high-FGF-23, and hyperphosphatemic state. (B) With calcitriol treatment in our rat model of CKD, levels of circulating calcitriol and PTH were both normalized back to control levels; however, serum FGF-23 was further increased beyond CKD levels, serum $\mathrm{Ca}^{2+}$ was elevated, and despite an increase in the expression of CYP24A1 the metabolite $1,24,25-(\mathrm{OH})_{3}-\mathrm{D}_{3}$ was still undetectable. These changes are indicated by the black arrows. considered in the management of this disease. Further research regarding the optimal therapeutic window of calcitriol is needed and will likely involve a more personalized medicine targeting multiple factors involved.

\section{Acknowledgments}

We acknowledge Andrew Edwards for assistance with histology.

\section{Authorship Contributions}

Participated in research design: McCabe, Zelt, Kaufmann, Jones, Adams, Holden.

Conducted experiments: McCabe, Zelt, Kaufmann, Laverty, Ward, Barron.

Contributed new reagents or analytic tools: Kaufmann, Jones.

Performed data analysis: McCabe, Zelt, Kaufmann.

Wrote or contributed to the writing of the manuscript: McCabe, Adams, Holden.

\section{References}

Andrade J and Ignaszewki A (2008) Cardiovascular risk assessment: identification of individuals at increased risk. BCMJ 50:246-251.

Batacchi Z, Robinson-Cohen C, Hoofnagle AN, Isakova T, Kestenbaum B, Martin KJ, Wolf MS, and de Boer IH (2017) Effects of vitamin $\mathrm{D}_{2}$ supplementation on vitamin $\mathrm{D}_{3}$ metabolism in health and CKD. Clin $J$ Am Soc Nephrol 12: 1498-1506.

Block GA (2001) Control of serum phosphorus: implications for coronary artery calcification and calcific uremic arteriolopathy (calciphylaxis). Curr Opin Nephrol Hypertens 10:741-747. Booth SL, Peterson JW, Smith D, Shea MK, Chamberland J, and Crivello N (2008) Age and dietary form of vitamin $\mathrm{K}$ affect menaquinone-4 concentrations in male Fischer 344 rats. J Nutr 138:492-496.

Briet M, Bozec E, Laurent S, Fassot C, London GM, Jacquot C, Froissart M, Houillier $\mathrm{P}$, and Boutouyrie $\mathrm{P}$ (2006) Arterial stiffness and enlargement in mild-to-moderate chronic kidney disease. Kidney Int 69:350-357.

Carrié I, Portoukalian J, Vicaretti R, Rochford J, Potvin S, and Ferland G (2004) Menaquinone-4 concentration is correlated with sphingolipid concentrations in rat brain. J Nutr 134:167-172.

Coresh J, Selvin E, Stevens LA, Manzi J, Kusek JW, Eggers P, Van Lente F, and Levey AS (2007) Prevalence of chronic kidney disease in the United States. JAMA 298:2038-2047.

Crenshaw TD, Rortvedt LA, and Hassen Z (2011) Triennial growth symposium: a novel pathway for vitamin D-mediated phosphate homeostasis: implications for skeleton growth and mineralization. J Anim Sci 89:1957-1964. 
Dai B, David V, Alshayeb HM, Showkat A, Gyamlani G, Horst RL, Wall BM, and Quarles LD (2012) Assessment of 24,25(OH)2D levels does not support FGF23mediated catabolism of vitamin D metabolites. Kidney Int 82:1061-1070.

de Boer IH, Sachs MC, Chonchol M, Himmelfarb J, Hoofnagle AN, Ix JH, Kremsdorf RA, Lin YS, Mehrotra R, Robinson-Cohen C, et al. (2014) Estimated GFR and circulating 24,25-dihydroxyvitamin $\mathrm{D}_{3}$ concentration: a participant-level analysis of 5 cohort studies and clinical trials. Am J Kidney Dis 64:187-197.

Doherty TM, Tang W, Dascalos S, Watson KE, Demer LL, Shavelle RM, and Detrano $\mathrm{RC}$ (1997) Ethnic origin and serum levels of $1 \alpha, 25$-dihydroxyvitamin $\mathrm{D}_{3}$ are independent predictors of coronary calcium mass measured by electron-beam computed tomography. Circulation 96:1477-1481.

Essalihi R, Dao HH, Yamaguchi N, and Moreau P (2003) A new model of isolated systolic hypertension induced by chronic warfarin and vitamin $\mathrm{K}_{1}$ treatment. $\mathrm{Am}$ J Hypertens 16:103-110.

Farzaneh-Far A, Weissberg PL, Proudfoot D, and Shanahan CM (2001) Transcriptional regulation of matrix gla protein. $Z$ Kardiol 90 (Suppl 3):38-42.

Faul C, Amaral AP, Oskouei B, Hu MC, Sloan A, Isakova T, Gutiérrez OM, AguillonPrada R, Lincoln J, Hare JM, et al. (2011) FGF23 induces left ventricular hypertrophy. J Clin Invest 121:4393-4408.

Fraser JD, Otawara Y, and Price PA (1988) 1,25-Dihydroxyvitamin $\mathrm{D}_{3}$ stimulates the synthesis of matrix $\gamma$-carboxyglutamic acid protein by osteosarcoma cells. Mutually exclusive expression of vitamin K-dependent bone proteins by clonal osteoblastic cell lines. J Biol Chem 263:911-916.

Fu X, Wang XD, Mernitz H, Wallin R, Shea MK, and Booth SL (2008) 9-Cis retinoic acid reduces $1 \alpha, 25$-dihydroxycholecalciferol-induced renal calcification by altering vitamin K-dependent $\gamma$-carboxylation of matrix $\gamma$-carboxyglutamic acid protein in A/J male mice. J Nutr 138:2337-2341.

Goldsmith DJ, Covic A, Sambrook PA, and Ackrill P (1997) Vascular calcification in long-term haemodialysis patients in a single unit: a retrospective analysis. Nephron 77:37-43.

Guérin AP, Blacher J, Pannier B, Marchais SJ, Safar ME, and London GM (2001) Impact of aortic stiffness attenuation on survival of patients in end-stage renal failure. Circulation 103:987-992.

Guérin AP, Pannier B, Marchais SJ, and London GM (2006) Cardiovascular disease in the dialysis population: prognostic significance of arterial disorders. Curr Opin Nephrol Hypertens 15:105-110.

Guérin AP, Pannier B, Métivier F, Marchais SJ, and London GM (2008) Assessment and significance of arterial stiffness in patients with chronic kidney disease. Curr Opin Nephrol Hypertens 17:635-641.

Gutiérrez OM, Mannstadt M, Isakova T, Rauh-Hain JA, Tamez H, Shah A, Smith K Lee H, Thadhani R, Jüppner H, et al. (2008) Fibroblast growth factor 23 and mortality among patients undergoing hemodialysis. N Engl J Med 359:584-592.

Haffner D, Hocher B, Müller D, Simon K, König K, Richter CM, Eggert B, Schwarz J, Godes M, Nissel R, et al. (2005) Systemic cardiovascular disease in uremic rats induced by 1,25(OH)2D3. J Hypertens 23:1067-1075.

Hasegawa H, Nagano N, Urakawa I, Yamazaki Y, Iijima K, Fujita T, Yamashita T, Fukumoto S, and Shimada T (2010) Direct evidence for a causative role of FGF23 in the abnormal renal phosphate handling and vitamin $\mathrm{D}$ metabolism in rats with early-stage chronic kidney disease. Kidney Int 78:975-980.

Helvig CF, Cuerrier D, Hosfield CM, Ireland B, Kharebov AZ, Kim JW, Ramjit NJ, Ryder K, Tabash SP, Herzenberg AM, et al. (2010) Dysregulation of renal vitamin $\mathrm{D}$ metabolism in the uremic rat. Kidney Int 78:463-472.

Henley C, Colloton M, Cattley RC, Shatzen E, Towler DA, Lacey D, and Martin D (2005) 1,25-Dihydroxyvitamin D3 but not cinacalcet HCl (Sensipar/Mimpara) treatment mediates aortic calcification in a rat model of secondary hyperparathyroidism. Nephrol Dial Transplant 20:1370-1377.

Heresztyn T and Nicholson BC (2001) A colorimetric protein phosphatase inhibition assay for the determination of cyanobacterial peptide hepatotoxins based on the dephosphorylation of phosvitin by recombinant protein phosphatase 1. Environ Toxicol 16:242-252.

Hill NR, Fatoba ST, Oke JL, Hirst JA, O'Callaghan CA, Lasserson DS, and Hobbs FDR (2016) Global prevalence of chronic kidney disease-a systematic review and meta-analysis. PLoS One 11:e0158765

Holden RM, Ki V, Morton AR, and Clase C (2012) Fat-soluble vitamins in advanced CKD/ESKD: a review. Semin Dial 25:334-343.

Holden RM, Sanfilippo AS, Hopman WM, Zimmerman D, Garland JS, and Morton AR (2007) Warfarin and aortic valve calcification in hemodialysis patients. $J$ Nephrol 20:417-422.

Inagaki O, Nakagawa K, Syono T, Nishian Y, Takenaka Y, and Takamitsu Y (1995) Effect of 1,25-dihydroxyvitamin $\mathrm{D}_{3}$ and diltiazem on tissue calcium in uremic rat. Ren Fail 17:651-657.

Isakova T, Xie H, Yang W, Xie D, Anderson AH, Scialla J, Wahl P, Gutiérrez OM, Steigerwalt S, He J, et al.; Chronic Renal Insufficiency Cohort (CRIC) Study Group (2011) Fibroblast growth factor 23 and risks of mortality and end-stage renal disease in patients with chronic kidney disease. JAMA 305:2432-2439.

Jean G, Terrat JC, Vanel T, Hurot JM, Lorriaux C, Mayor B, and Chazot C (2009) High levels of serum fibroblast growth factor (FGF)-23 are associated with in creased mortality in long haemodialysis patients. Nephrol Dial Transplant 24 $2792-2796$

Jones G (2007) Expanding role for vitamin D in chronic kidney disease: importance of blood 25-OH-D levels and extra-renal $1 \alpha$-hydroxylase in the classical and nonclassical actions of $1 \alpha, 25$-dihydroxyvitamin $\mathrm{D}_{3}$. Semin Dial 20:316-324

Jones G, Prosser DE, and Kaufmann M (2012) 25-Hydroxyvitamin D-24-hydroxylase (CYP24A1): its important role in the degradation of vitamin D. Arch Biochem Biophys 523:9-18.

Jüppner H, Wolf M, and Salusky IB (2010) FGF-23: more than a regulator of renal phosphate handling? J Bone Miner Res 25:2091-2097.

Kaesler N, Magdeleyns E, Herfs M, Schettgen T, Brandenburg V, Fliser D, Vermeer C, Floege J, Schlieper G, and Krüger T (2014) Impaired vitamin K recycling in uremia is rescued by vitamin $\mathrm{K}$ supplementation. Kidney Int 86:286-293.
Kaufmann M, Gallagher JC, Peacock M, Schlingmann KP, Konrad M, DeLuca HF, Sigueiro R, Lopez B, Mourino A, Maestro M, et al. (2014) Clinical utility of simultaneous quantitation of 25-hydroxyvitamin $\mathrm{D}$ and 24,25-dihydroxyvitamin D by LC-MS/MS involving derivatization with DMEQ-TAD. J Clin Endocrinol Metab 99:2567-2574.

Kaufmann M, Morse N, Molloy BJ, Cooper DP, Schlingmann KP, Molin A, Kottler ML, Gallagher JC, Armas L, and Jones G (2017) Improved screening test for idiopathic infantile hypercalcemia confirms residual levels of serum $24,25-(\mathrm{OH})_{2} \mathrm{D}_{3}$ in affected patients. J Bone Miner Res 32:1589-1596.

Kendrick J, Cheung AK, Kaufman JS, Greene T, Roberts WL, Smits G, and Chonchol M; HOST Investigators (2011) FGF-23 associates with death, cardiovascular events, and initiation of chronic dialysis. J Am Soc Nephrol 22:1913-1922.

Koleganova N, Piecha G, Ritz E, Schmitt CP, and Gross ML (2009) A calcimimetic (R-568), but not calcitriol, prevents vascular remodeling in uremia. Kidney Int $\mathbf{7 5}$ $60-71$.

Krueger T, Westenfeld R, Ketteler M, Schurgers LJ, and Floege J (2009) Vitamin K deficiency in CKD patients: a modifiable risk factor for vascular calcification? Kidney Int 76:18-22.

Lau WL, Festing MH, and Giachelli CM (2010) Phosphate and vascular calcification: emerging role of the sodium-dependent phosphate co-transporter PiT-1. Thromb Haemost 104:464-470.

Lau WL, Leaf EM, Hu MC, Takeno MM, Kuro-o M, Moe OW, and Giachelli CM (2012 Vitamin D receptor agonists increase klotho and osteopontin while decreasing aortic calcification in mice with chronic kidney disease fed a high phosphate diet. Kidney Int 82:1261-1270.

Levin A, Hemmelgarn B, Culleton B, Tobe S, McFarlane P, Ruzicka M, Burns K, Manns B, White C, Madore F, et al.; Canadian Society of Nephrology (2008) Guidelines for the management of chronic kidney disease. CMAJ 179:1154-1162.

Lomashvili KA, Narisawa S, Millán JL, and O'Neill WC (2014) Vascular calcification is dependent on plasma levels of pyrophosphate. Kidney Int 85:1351-1356.

Lomashvili KA, Wang X, Wallin R, and O'Neill WC (2011) Matrix Gla protein metabolism in vascular smooth muscle and role in uremic vascular calcification. $J$ Biol Chem 286:28715-28722.

London GM, Blacher J, Pannier B, Guérin AP, Marchais SJ, and Safar ME (2001) Arterial wave reflections and survival in end-stage renal failure. Hypertension 38 : 434-438.

London GM, Guérin AP, Marchais SJ, Métivier F, Pannier B, and Adda H (2003) Arterial media calcification in end-stage renal disease: impact on all-cause and cardiovascular mortality. Nephrol Dial Transplant 18:1731-1740.

Luo G, Ducy P, McKee MD, Pinero GJ, Loyer E, Behringer RR, and Karsenty G (1997) Spontaneous calcification of arteries and cartilage in mice lacking matrix GLA protein. Nature 386:78-81.

Mathew S, Lund RJ, Chaudhary LR, Geurs T, and Hruska KA (2008) Vitamin D receptor activators can protect against vascular calcification. J Am Soc Nephrol 19: $1509-1519$

McCabe KM, Booth SL, Fu X, Shobeiri N, Pang JJ, Adams MA, and Holden RM (2013) Dietary vitamin K and therapeutic warfarin alter the susceptibility to vascular calcification in experimental chronic kidney disease. Kidney Int $\mathbf{8 3}$ : $835-844$

Melamed ML, Eustace JA, Plantinga L, Jaar BG, Fink NE, Coresh J, Klag MJ, and Powe NR (2006) Changes in serum calcium, phosphate, and PTH and the risk of death in incident dialysis patients: a longitudinal study. Kidney Int 70:351-357.

Mizobuchi M, Finch JL, Martin DR, and Slatopolsky E (2007) Differential effects of vitamin $\mathrm{D}$ receptor activators on vascular calcification in uremic rats. Kidney Int 72:709-715.

Naves-Díaz M, Alvarez-Hernández D, Passlick-Deetjen J, Guinsburg A, Marelli C, Rodriguez-Puyol D, and Cannata-Andía JB (2008) Oral active vitamin D is associated with improved survival in hemodialysis patients. Kidney Int 74:1070-1078

Nigwekar SU, Bhan I, and Thadhani R (2012) Ergocalciferol and cholecalciferol in CKD. Am J Kidney Dis 60:139-156.

Pannier B, Guérin AP, Marchais SJ, Safar ME, and London GM (2005) Stiffness of capacitive and conduit arteries: prognostic significance for end-stage renal disease patients. Hypertension 45:592-596.

Parker BD, Schurgers LJ, Brandenburg VM, Christenson RH, Vermeer C, Ketteler M, Shlipak MG, Whooley MA, and Ix JH (2010) The associations of fibroblast growth factor 23 and uncarboxylated matrix Gla protein with mortality in coronary artery disease: the heart and soul study. Ann Intern Med 152:640-648.

Petkovich M and Jones G (2011) CYP24A1 and kidney disease. Curr Opin Nephrol Hypertens 20:337-344.

Price PA, Faus SA, and Williamson MK (2000) Warfarin-induced artery calcification is accelerated by growth and vitamin D. Arterioscler Thromb Vasc Biol 20:317-327.

Price PA, Roublick AM, and Williamson MK (2006) Artery calcification in uremic rats is increased by a low protein diet and prevented by treatment with ibandronate. Kidney Int 70:1577-1583.

Proudfoot D and Shanahan CM (2006) Molecular mechanisms mediating vascular calcification: role of matrix Gla protein. Nephrology (Carlton) 11:455-461.

Proudfoot D, Skepper JN, Hegyi L, Bennett MR, Shanahan CM, and Weissberg PL (2000) Apoptosis regulates human vascular calcification in vitro: evidence for initiation of vascular calcification by apoptotic bodies. Circ Res 87:1055-1062.

Proudfoot D, Skepper JN, Shanahan CM, and Weissberg PL (1998) Calcification of human vascular cells in vitro is correlated with high levels of matrix Gla protein and low levels of osteopontin expression. Arterioscler Thromb Vasc Biol 18 379-388

Quarles LD (2012) Role of FGF23 in vitamin D and phosphate metabolism: implications in chronic kidney disease. Exp Cell Res 318:1040-1048.

Raggi P, Chertow GM, Torres PU, Csiky B, Naso A, Nossuli K, Moustafa M, Goodman WG, Lopez N, Downey G, et al.; ADVANCE Study Group (2011) The ADVANCE study: a randomized study to evaluate the effects of cinacalcet plus low-dose vitamin D on vascular calcification in patients on hemodialysis. Nephrol Dial Transplant 26:1327-1339. 
Razzaque MS (2011) The dualistic role of vitamin D in vascular calcifications. Kidney Int 79:708-714.

Reynolds JL, Joannides AJ, Skepper JN, McNair R, Schurgers LJ, Proudfoot D, Jahnen-Dechent W, Weissberg PL, and Shanahan CM (2004) Human vascular smooth muscle cells undergo vesicle-mediated calcification in response to changes in extracellular calcium and phosphate concentrations: a potential mechanism for accelerated vascular calcification in ESRD. J Am Soc Nephrol 15:2857-2867.

Rodriguez M, Martinez-Moreno JM, Rodríguez-Ortiz ME, Muñoz-Castañeda JR, and Almaden Y (2011) Vitamin D and vascular calcification in chronic kidney disease. Kidney Blood Press Res 34:261-268.

Safar ME, Blacher J, Pannier B, Guerin AP, Marchais SJ, Guyonvarc'h PM, and London GM (2002) Central pulse pressure and mortality in end-stage renal disease. Hypertension 39:735-738.

Seiler S, Reichart B, Roth D, Seibert E, Fliser D, and Heine GH (2010) FGF-23 and future cardiovascular events in patients with chronic kidney disease before initiation of dialysis treatment. Nephrol Dial Transplant 25:3983-3989.

Shobeiri N, Pang J, Adams MA, and Holden RM (2013) Cardiovascular disease in an adenine-induced model of chronic kidney disease: the temporal link between vascular calcification and haemodynamic consequences. $J$ Hypertens 31:160-168.

Sweatt A, Sane DC, Hutson SM, and Wallin R (2003) Matrix Gla protein (MGP) and bone morphogenetic protein-2 in aortic calcified lesions of aging rats. $J$ Thromb Haemost 1:178-185.

Teng M, Wolf M, Lowrie E, Ofsthun N, Lazarus JM, and Thadhani R (2003) Survival of patients undergoing hemodialysis with paricalcitol or calcitriol therapy. $N$ Engl $J$ Med 349:446-456.

Teng M, Wolf M, Ofsthun MN, Lazarus JM, Hernán MA, Camargo CA, Jr, and Thadhani R (2005) Activated injectable vitamin D and hemodialysis survival: a historical cohort study. J Am Soc Nephrol 16:1115-1125.

Tentori F, Hunt WC, Stidley CA, Rohrscheib MR, Bedrick EJ, Meyer KB, Johnson HK, and Zager PG; Medical Directors of Dialysis Clinic Inc. (2006) Mortality risk among hemodialysis patients receiving different vitamin D analogs. Kidney Int 70:1858-1865.

Terai K, Nara H, Takakura K, Mizukami K, Sanagi M, Fukushima S, Fujimori A, Itoh H, and Okada M (2009) Vascular calcification and secondary hyperparathyroidism of severe chronic kidney disease and its relation to serum phosphate and calcium levels. Br J Pharmacol 156:1267-1278. ter Braake AD, Tinnemans PT, Shanahan CM, Hoenderop JGJ, and de Baaij JHF (2018) Magnesium prevents vascular calcification in vitro by inhibition of hydroxyapatite crystal formation. Sci Rep 8:2069.

Ureña-Torres PA, Floege J, Hawley CM, Pedagogos E, Goodman WG, Pétavy F, Reiner M, and Raggi P (2013) Protocol adherence and the progression of cardiovascular calcification in the ADVANCE study. Nephrol Dial Transplant 28: $146-152$.

Watson KE, Abrolat ML, Malone LL, Hoeg JM, Doherty T, Detrano R, and Demer LL (1997) Active serum vitamin D levels are inversely correlated with coronary calcification. Circulation 96:1755-1760.

Wolf M (2010) Forging forward with 10 burning questions on FGF23 in kidney disease. J Am Soc Nephrol 21:1427-1435.

Wolf M, Betancourt J, Chang Y, Shah A, Teng M, Tamez H, Gutierrez O, Camargo CA, Jr, Melamed M, Norris K, et al. (2008) Impact of activated vitamin D and race on survival among hemodialysis patients. J Am Soc Nephrol 19:1379-1388.

Wu-Wong JR, Nakane M, Ma J, Ruan X, and Kroeger PE (2006a) Effects of vitamin D analogs on gene expression profiling in human coronary artery smooth muscle cells. Atherosclerosis 186:20-28.

Wu-Wong JR, Noonan W, Ma J, Dixon D, Nakane M, Bolin AL, Koch KA, Postl S, Morgan SJ, and Reinhart GA (2006b) Role of phosphorus and vitamin D analogs in the pathogenesis of vascular calcification. J Pharmacol Exp Ther 318:90-98.

Zaragatski E, Grommes J, Schurgers LJ, Langer S, Kennes L, Tamm M, Koeppel TA, Kranz J, Hackhofer T, Arakelyan K, et al. (2016) Vitamin K antagonism aggravates chronic kidney disease-induced neointimal hyperplasia and calcification in arterialized veins: role of vitamin $\mathrm{K}$ treatment? Kidney Int $\mathbf{8 9}$ : 601-611.

Address correspondence to: Dr. Rachel M. Holden, Department of Medicine, Queen's University, Kingston, ON K7L 3V6, Canada. E-mail: holdenr@kgh.kari.net; or Dr. Michael A. Adams, Queen's University, Department of Biomedical and Molecular Sciences, Kingston, ON K7L 3V6, Canada. E-mail: adams@queensu.ca 